\title{
Integrative stratigraphy and climatic events of a new lower Paleogene reference section from the Betic Cordillera: Río Gor, Granada province, SE Spain
}

\author{
Victoriano PUJALTE ${ }^{1 *}$, Estibaliz APELLANIZ ${ }^{1}$, Fernando CABALLERO ${ }^{1}$, Simonetta \\ MONECHI ${ }^{2}$, Silvia ORTIZ ${ }^{3}$, Xabier ORUE-ETXEBARRIA ${ }^{1}$, Francisco J. RODRÍGUEZ- \\ TOVAR ${ }^{4}$ \& Birger SCHMITZ
}

\footnotetext{
${ }^{1}$ Department of Stratigraphy and Paleontology, Faculty of Science and Technology, University of the Basque Country UPV/ EHU, Ap. 644, 48080 Bilbao, Spain

${ }^{2}$ Dipartimento di Scienze della Terra, Università di Firenze, Via La Pira 4, I-50121 Firenze, Italy

${ }^{3}$ PetroStrat Ltd, Tan-y-Graig, Parc Caer Seion, Conwy, Wales, UK, LL32 8FA

${ }^{4}$ Department of Stratigraphy and Paleontology, Faculty of Science, University of Granada, 18002 Granada, Spain

${ }^{5}$ Division of Nuclear Physics, Department of Physics, University of Lund, P.O. Box 118, SE-221 00 Lund, Sweden

* Corresponding author

Pujalte, V., Apellaniz, E., Caballero, F., Monechi, S., Ortiz, S., Orue-Etxebarria, X., Rodríguez-Tovar, F.J. \& Schmitz, B. 2017. Integrative stratigraphy and climatic events of a new lower Paleogene reference section from the Betic Cordillera: Río Gor, Granada province, SE Spain. [Estratigrafía integrada en una nueva sección de referencia del Paleógeno inferior de la Cordillera Bética: Río Gor, provincia de Granada, SE España]. Spanish Journal of Palaeontology, 32 (1), 185-206.
}

\section{ABSTRACT}

Research interest in the early Paleogene was greatly enhanced after the recognition of several short-lived warming events in that period (hyperthermals), considered ancient analogues of the ongoing warming of the Earth climate. In the Caravaca and Alamedilla sections, the previously most studied lower Paleogene sections of the Subbetic Zone (Betic Cordillera), only the most prominent of these hyperthermals had been located, the so-called Paleocene/Eocene Thermal Maximum. The Río Gor section, though less studied, is found to comprise a lower Paleogene succession that is more expanded and complete than Caravaca and Alamedilla; it contains record of the Early Late Paleocene and Paleocene/Eocene Thermal Events, and at least one additional Eocene hyperthermal, thus offering an excellent opportunity to study these climatic events in the Subbetic Zone. Study of the Río Gor section is still in progress, this paper summarizing the state-of-the art of ongoing research.

Keywords: Early Paleogene, hyperthermals, ELPE, PETM, Río Gor, Subbetic Zone.

\section{RESUMEN}

El interés por la investigación del Paleógeno inferior se vio muy reforzado tras el descubrimiento durante dicho Periodo de varios eventos de calentamiento climático de corta duración (hipertermales), considerados antiguos análogos del actual proceso de calentamiento del clima de la Tierra. En las secciones de Caravaca y Alamedilla, las más estudiadas hasta la fecha del Paleógeno inferior en la zona Subbética (Cordillera Bética), sólo el más prominente de dichos hipertermales ha sido localizado hasta el momento, el llamado Máximo Térmico del Paleoceno/Eoceno. La sección de Río Gor, hasta ahora menos estudiada, comprende una sucesión del Paleógeno inferior más expandida y completa que las de Caravaca y Alamedilla, y contiene registros de al menos dos hipertermales, el del Paleoceno Inferior Superior y el del Paleoceno/Eoceno, y al menos de otro del Eoceno, y ofrece por ello una excelente oportunidad para estudiar estos eventos climáticos en la Zona Subbética. El estudio de la sección de Río Gor y de sus eventos hipertermales está en aún en curso, sintetizándose en este trabajo el estado actual de conocimientos.

Palabras clave: Paleógeno inferior, hipertermales, ELPE, PETM, Río Gor, Zona Subbética. 


\section{INTRODUCTION}

The Earth's climate underwent long-term warming during the early Paleogene that climaxed in the early Eocene, when subtropical forests existed at latitudes above $60^{\circ}$ (Zachos et al., 2008). Superimposed on this trend, several short-term events of extreme warmth have been discovered, the so-called hyperthermals (Thomas \& Zachos, 2000; Zachos et al., 2010). Hyperthermals are characterized by carbon isotopic excursions (CIEs) recording the release of massive volumes of ${ }^{13} \mathrm{C}$-depleted carbon into the ocean and atmosphere. The first and most prominent of these events to be identified is the Paleocene/Eocene Thermal Maximum (PETM), also named the Late Paleocene Thermal Maximum (LPTM), the Initial Eocene Thermal Maximum (IETM), or the Eocene Thermal Maximum-1 (ETM-1; Sluijs et al., 2007). The exact number of early Paleogene hyperthermals is still undetermined, as the amount of warming necessary to qualify an event as such is somewhat imprecise (Coccioni et al., 2012). There is a general consensus, however, that at least two main hyperthermals occurred during Paleocene times, one of them labeled either as the Latest Danian Event (LDE, Bornemann et al., 2009; Monechi et al., 2012), or Top Chron C27n Event (TC27N, Schulte et al., 2010; DinarèsTurell et al., 2012), the other as the Early Late Paleocene Event (ELPE, Petrizzo, 2005) or Mid-Paleocene Biotic Event (MPBE; Bernaola et al., 2007; Hyland et al., 2015). The number of Eocene hyperthermals is higher (Nicolo et al., 2007), the three most widely acknowledged being termed Eocene Thermal Maximum 2 (ETM2; also H1 or Elmo), H2, and Eocene Thermal Maximum 3 (ETM3; also K or X; Lourens et al., 2005; Röhl et al., 2005; Nicolo et al., 2007; Agnini et al., 2009; Stap et al., 2010; Zachos et al., 2010). It is suspected that additional hyperthermals may have occurred during the Eocene (e.g., Coccioni et al., 2012; Payros et al., 2012).

Hyperthermal events are regarded as ancient analogues of the current warming of the Earth's climate, and have consequently attracted much scientific attention (e.g., Zachos et al., 2008; Zeebe et al., 2009; Hönisch et al., 2012). Furthermore, as they are global and synchronous events, they are excellent tools for intra- and inter-basinal stratigraphic correlations. Not surprisingly, the base of the PETM was chosen to delineate the Paleocene/Eocene (P/E) boundary (Aubry et al., 2007), while the ELPE can be used to approximate the Selandian/Thanetian boundary (Schmitz et al., 2011).

Several early Paleogene hyperthermals have been pinpointed in the Pyrenean domain. The PETM, in particular, is recognized in terrestrial deposits (Schmitz \& Pujalte, 2003, 2007; Domingo et al., 2009; Minelli et al., 2013), and in shallow marine, base-of-slope and deep marine settings of the southern Pyrenees and the Basque Basin (e.g., Canudo \& Molina, 1992; Canudo et al., 1995; Schmitz et al., 1997, 2001; Pujalte et al., 2003, 2015a, 2016; Robador et al., 2009; Rodríguez-Tovar et al., 2011; Storme et al., 2012), a recognition leading to a refined correlation of the sedimentary records of these different settings across the P/E interval (e.g., Schmitz \& Pujalte, 2003; Pujalte et al., 2009). Other hyperthermals recognized in the Basque Basin include the LDE/TC27N (Dinarès-Turell et al., 2012), the ELPE/MPBE (Bernaola et al., 2007), and an early Lutetian event termed Chron 21r-H6 (Payros et al., 2012).

In the Betic Cordillera, the PETM has been reported and amply studied in the Caravaca and Alamedilla sections (e.g., Angori \& Monechi, 1996; Arenillas \& Molina, 1996; Guernet \& Molina, 1997; Lu et al., 1998; Monechi et al., 2000; Aubry et al., 2006; Angori et al., 2007; Alegret et al., 2009b, 2010; Arreguín-Rodríguez et al., 2014). Until recently, however, no other Paleogene hyperthermals had been recognized. The possible reasons for the scarce record could be outcrop limitations in the Caravaca section, and several important hiatuses in the Alamedilla section. The Río Gor section, studied here, offers a better opportunity to identify additional hyperthermal events, as it comprises a well-exposed and expansive lower Paleogene succession (Pujalte et al., 2012). Indeed, the ELPE has already been pinpointed in this section (Pujalte et al., 2014b), the PETM is positively identified in this paper, and the location of a prospective Eocene hypertermal is indicated.

The analysis of the Río Gor section is still in progress, the purpose of this study being to update the current state of research. Accordingly: 1) The lithostratigraphy of the section is described and age-dated with planktic foraminifera; 2) a preliminary account of the abundant ichnofossils is provided, which together with data of benthic foraminifera is used to estimate the depositional context of the succession; 3 ) the distinctive isotopic and biotic features of the ELPE and the PETM hyperthermals are described and compared with their equivalents in the Basque Basin; and, 4) preliminary calcareous plankton and planktic foraminifera data from a prospective Eocene hyperthermal are provided.

\section{GEOLOGICAL CONTEXT AND PREVIOUS WORK}

The External Zones of the Betic Cordillera contain a thick Triassic to lower Miocene sedimentary succession deposited on the southern continental margin of the Iberian Plate, thus on the north-westernmost margin of the Tethys Ocean. The External Zones are subdivided in two parts, the Prebetic and Subbetic Zones, which roughly correspond, respectively, to shallow and deep-marine domains. Tectonic deformation occurred during Miocene 
times by collision with the Mesomediterranean microplate, its remains represented today by the Betic Internal Zones (Fig. 1a; Vera, 2004).

Caravaca, Alamedilla and Río Gor, the three sections in which early Paleogene hyperthermal events have been reported so far, are situated in the Subbetic Zone (Fig. 1). Caravaca and Alamedilla are well-known, as they are stratotypic sections for, respectively, the Jorquera Formation (Maastrichtian-lower Eocene; Van Veen, 1969) and the Capas Rojas Formation (Campanian-lower Eocene; Vera et al., 1982). Both formations mainly consist of marls and marly limestones, which in the Jorquera Formation are predominantly whitish and in the Capas Rojas Formation pink in color.

The Caravaca section is situated along the Barranco del Gredero, about $3 \mathrm{~km}$ southwest of the city Caravaca de la Cruz (longitude/latitude 38 04'39'/ $1^{\circ} 52^{\prime} 48^{\prime \prime}$ ) (Smit, 1979, 2004; De Paolo et al., 1983; Molina et al., 1994; Kaiho \& Lamolda, 1999; Rodríguez-Tovar \& Uchman, 2006, 2008; Kedzierski et al., 2011; Sosa et al., 2013, 2016). The section occurs along a forested dry creek and it is not continuously exposed (Fig. 2a), its Paleocene and Ypresian segments respectively being about 125 and $75 \mathrm{~m}$ thick (Hillebrandt, 1974).

The Alamedilla section $\left(37^{\circ} 34^{\prime} 15^{\prime \prime} / 3^{\circ} 14^{\prime} 20^{\prime \prime}\right)$ is situated along the Barranco de los Valencianos (Figs. 1b, 2b). The Paleocene segment is only about $16 \mathrm{~m}$ thick and the Ypresian segment around $110 \mathrm{~m}$ thick (MartínezGallego, 1977; Gonzalvo \& Molina, 1988; Arenillas \& Molina, 1996; Pujalte et al., 2012). The reduced thickness of the Paleocene segment is mainly due to the existence of hiatuses, the most important one encompassing most of the Danian, the entire Selandian and the lower part of the Thanetian (Pujalte et al., 2012, 2014a).

The Río Gor section lies in the province of Granada, $1.5 \mathrm{~km}$ to the ENE of the Alicún de Las Torres Spa and about $14 \mathrm{~km} \mathrm{SE}$ of the Alamedilla section (Fig. 1b), and it is affected by a prominent thrust fault (Fig. 3). The bulk of the section occurs in the hanging block of the fault, along the La Leña ravine, a tributary of the Gor River (base at $37^{\circ} 30^{\prime} 49^{\prime \prime} / 3^{\circ} 05^{\prime \prime} 36^{\prime \prime}$; top at $37^{\circ} 31^{\prime} 05^{\prime \prime} / 3^{\circ} 05^{\prime} 09^{\prime \prime}$ ). The uppermost part of the section is also well exposed in the foot wall of the thrust fault, alongside the north (righthand) margin of the Gor River valley (Fig. 3a). The main part of the section at the La Leña ravine is approximately $320 \mathrm{~m}$ thick, its Paleocene and Ypresian segments being respectively $232 \mathrm{~m}$ and $78 \mathrm{~m}$ thick (Fig. 3b). In the footwall of the thrust fault, at least $40 \mathrm{~m}$ of Lutetian deposits have been identified (Pujalte et al., 2012). The section is therefore thicker than Caravaca and Alamedilla, especially its Paleocene segment.

Previous data about the Río Gor section are sparse, probably because it is less accessible than the Caravaca and Alamedilla sections. Comas (1978, p. 168) reported that "in the Gor river valley the Olivares Formation [i.e., Danian-lower Selandian, see below] is outcropped, but affected by tectonic structures and partly covered by Pliocene conglomerates". Paleocene and Eocene deposits are differentiated in the 1:50,000 sheet 993 (Benalúa de Guadix) of the National Geological Map of Spain (Roldán García et al., 2009), but the existence of the thrust fault that duplicates part of the succession was overlooked, and no lithological log of the section was supplied. Pujalte et al. (2012) were the first to point out the expanded character of the section based on a study of the planktic foraminifers of 20 samples. Because of the limited number of samples, some with poorly preserved microfossils, a prominent interval of red-bed marls from the La Leña ravine segment of the section was mistakenly attributed to the PETM, although a later study unambiguously demonstrated that it corresponds to the ELPE (Pujalte $e t$ al., 2014b).

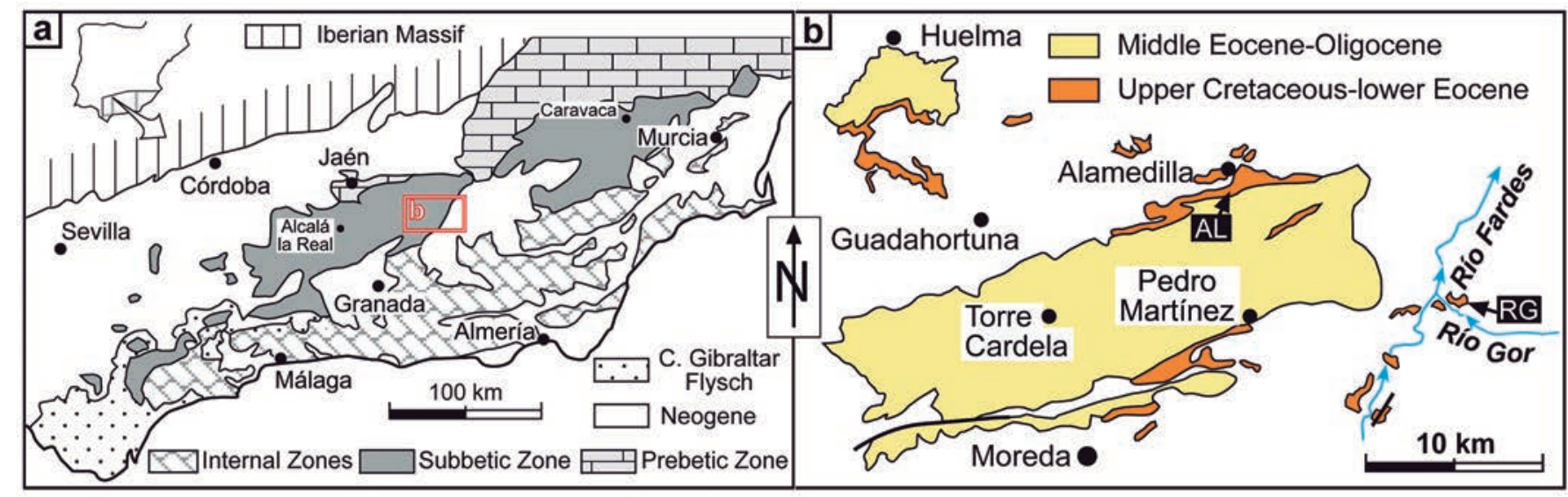

Figure 1. a) Simplified geological map of the Betic Cordillera and situation of the study area and of the villages of Caravaca and Alcalá la Real. b) Paleogene outcrops of the study area and location of the Alamedilla (AL) and Río Gor (RG) sections. 

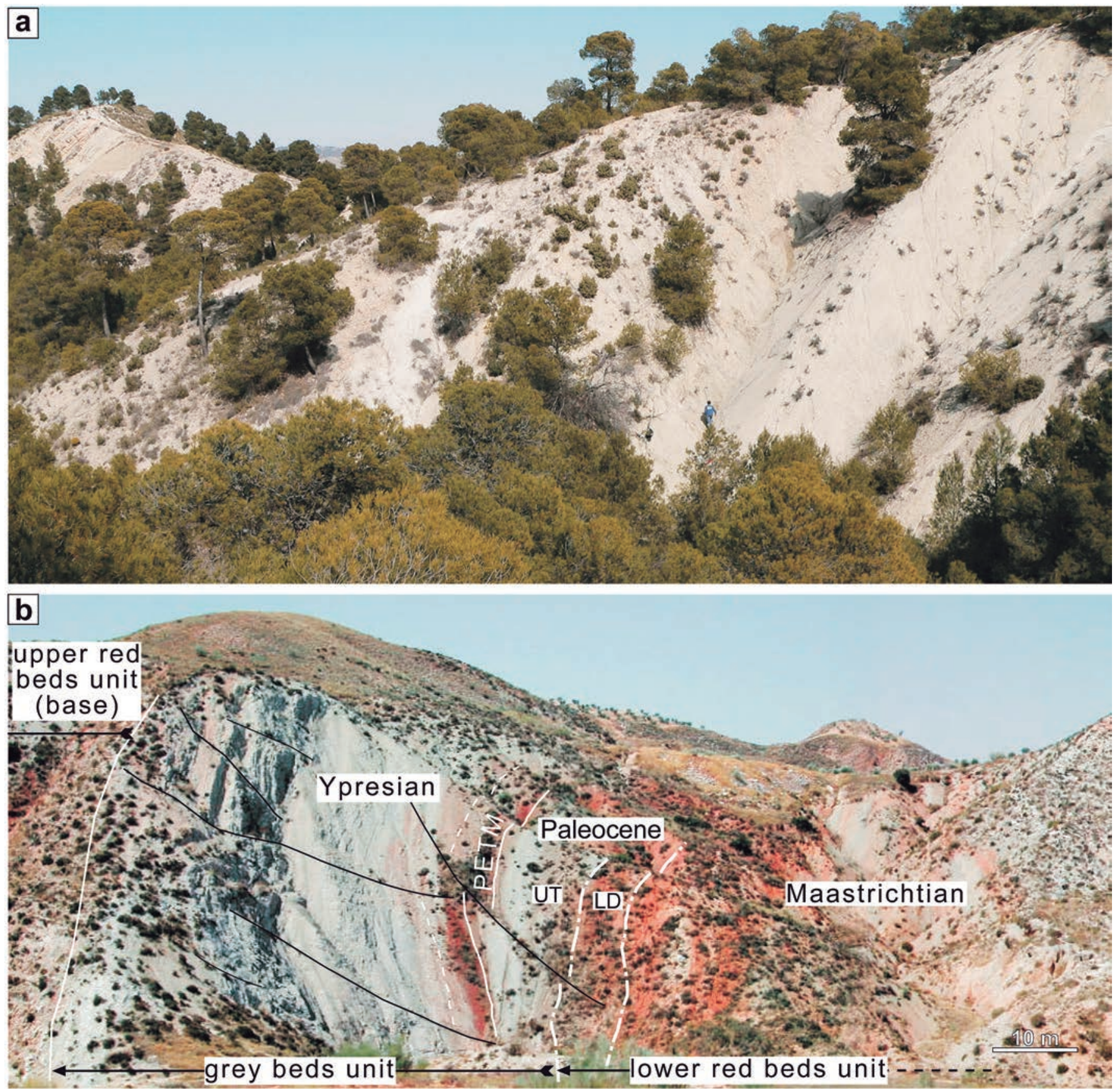

Figure 2. a) Field view of the middle part of the Caravaca section at the forested Gredero ravine (courtesy of Prof. Alfred Uchman). Geologist near the bottom right is for scale. b) Field view of the upper Maastrichtian/lower Eocene interval of the Alamedilla section showing the lower red beds unit, the grey beds unit and the PETM interval. Note the upper Maastrichtian deep-red marls, the reduced thickness of the Paleocene interval $(\sim 16 \mathrm{~m})$ and the important hiatus between the lower Danian (LD) and upper Thanetian (UT) deposits.

\section{METHODS AND DATA SET}

A new geological map of the study area was created by transferring field observations to satellite colour images from Google Earth (Fig. 3a). A total of 73 samples were collected (distribution in Fig. 3b), all analyzed for planktic and benthic foraminifers. In addition, the samples of the hyperthermal intervals were processed for calcareous nannoplankton and for organic carbon isotopes.

Samples for planktic and benthic foraminifers, each of about $1 \mathrm{~kg}$, were collected from marly beds and washed through 100-500 $\mu \mathrm{m}$ mesh. Most residue contained 
sufficient foraminifers to allow for a semi-quantitative study, designed to identify a sufficient number of marker species. Paleobathymetrical inferences were mainly based on benthic foraminiferal data, with the addition of ichnological information. Benthic foraminiferal identification followed van Morkhoven et al. (1986) and Tjalsma \& Lohmann (1983).

Calcareous nannoplankton was analyzed in samples from the hyperthermal events. Qualitative investigations were carried out on two traverses of each smear slide to check for common and very rare species.

Analyses of the organic carbon $\left({ }^{13} \mathrm{C}_{\text {org }}\right)$ were carried out at the Servizos de Apoio á Investigación (SAI) of the University of A Coruña, Spain. Samples were weighed in silver capsules, decarbonated using $25 \% \mathrm{HCl}$, and measured by continuous flow isotope ratio mass spectrometry using a MAT253 mass spectrometer (ThermoFinnigan) coupled to an elemental analyzer EA1108 (Carlo Erba Instruments) through a Conflo III interface (ThermoFinnigan). Carbon isotope abundance is expressed as ${ }^{13} \mathrm{C}_{\text {org }}(\%)$ relative to VPDB. International reference standards (NBS-22, IAEACH-6 and USGS 24) were used for ${ }^{13} \mathrm{C}$ calibration.

Trace fossil analysis is based on outcrop observations, with special attention to the stratigraphic distribution of ichnofossil assemblages and their relationship with differentiated facies. Macroscopic morphological features focus on: orientation, shape, dimensions and configuration of the burrow systems, as well as taphonomic features. Attention was paid to the relative abundance of traces. Close-up photographs were taken of the registered specimens.

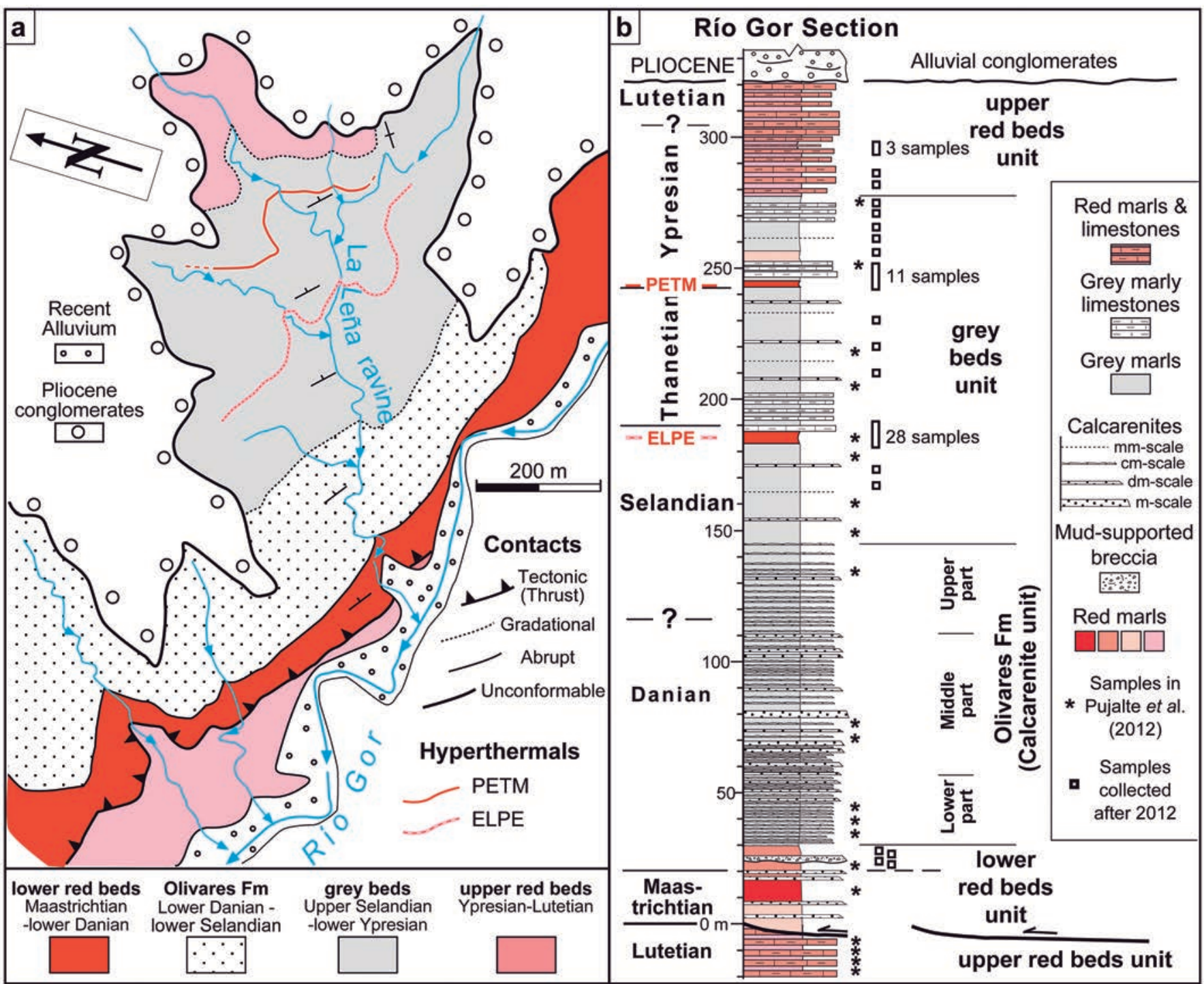

Figure 3. a) Geological map of the Río Gor area. b) Synthetic litholog of the Río Gor section, with indication of its constituent formal and informal lithostratigraphic units. Lithological key and position of the studied samples within the inset. 


\section{RESULTS}

\subsection{Lithostratigraphy and biostratigraphy}

The Río Gor section comprises four lithostratigraphic units, one of them formally defined by Comas (1978) as the Olivares Formation, and the other three informally named, according to their dominant colours, as the lower red beds, grey beds and upper red beds (Fig. 3). The areal extent of the Olivares Formation is limited to the Fardes and Gor river valleys (Comas, 1978), although a unit of similar features, the Majalcorón Formation, was reported by Molina et al. (2006) to the south of Alcalá la Real, Jaén province (Fig. 1a). In contrast, the three informal units are widespread, found also in the Alamedilla section (Fig. 2b).

The lower red beds unit is incomplete at the Río Gor section, as its base is truncated by the thrust fault that superimposed the La Leña ravine segment of the section onto Eocene deposits (Fig. 3). The preserved part ( $\sim 30 \mathrm{~m}$ ) mostly consists of marls of different shades, with light-red marls in the lower and upper parts of the unit separated by a middle interval of deep-red marls (Fig. 4a). The unit also contains several calciturbidite beds with prominent Tabc and Tbc Bouma sequences ranging $5-40 \mathrm{~cm}$ in thickness, and, at least, a mud-supported breccia about $1 \mathrm{~m}$ thick, with limestone clasts embedded in a marly matrix (Fig. 3b). The planktic foraminiferal assemblage from the lower light-red and the middle deep-red marls is dominated by Heterohelicids and Globotruncanids, including Abathomphalus mayaroensis, the index species of the upper Maastrichtian (Mary et al., 1991; Apellaniz et al., 1996). In turn, the upper light-red marls contain, among other species, Globanomalina compressa and Praecursoria inconstans, which indicate the early Danian P1c biozone of Wade et al. (2011). The absence of the biozones P0, P1a and P1b of Wade et al. (2011) at the boundary between the middle and the light-red upper marls entails a hiatus of at least 2.5 Ma, which includes the K/Pg boundary (Fig. $3 \mathrm{~b}$ ).

The Olivares Formation is $\sim 110 \mathrm{~m}$ thick, with a sharp base and a gradational top (Figs $3 b, 4 b$ ). It mainly comprises light- and medium-grey calcarenites, with intercalations of light-grey marls in variable proportions. The calcarenites have a peculiar composition, as they largely consist (40-90\%) of Microcodium remains, mainly disaggregated prisms, yet less frequently, fragmented rosettes. Microcodium, in effect, is thought to have been originally formed in carbonate-rich soils in association with plant roots (e.g., Klappa, 1978; Kosir, 2004; Molina et al., 2006), its occurrence in large volumes within a marine basin thus being remarkable. In addition, the calcarenites include smaller amounts of intraclasts, miliolids, quartz grains and, occasionally, ooids. Two types of calcarenites, thin- and thick-bedded, are readily differentiated (Fig. 5). Thin-bedded calcarenites occur as laterally extensive beds $5-15 \mathrm{~cm}$-thick, most of them in the lower part of the range. These beds have flat bases and undulating tops, some exhibiting weakly defined cross laminations, but most having a massive appearance (Fig. $5 \mathrm{a}$ ), and their origin is somewhat controversial (Pujalte et al., 2015b). Thick-bedded calcarenites usually range 20$50 \mathrm{~cm}$ in thickness, but a few of them exceed $60 \mathrm{~cm}$ and one reaches $180 \mathrm{~cm}$. They exhibit well-developed Tabc or Tbc Bouma sequences and thus are confidently classified as calciturbidites (Fig. 5b).

The relative proportion of the lithologies of the Olivares Formation varies throughout the section, and three divisions can be recognized (Figs 3b, 4b). The lower division is dominated by thin-bedded calcarenites separated by thin marly intercalations. The middle division includes thinbedded calcarenites, calciturbidites, and a $\sim 20 \%$ proportion of marls. The upper division consists of alternations of thin-bedded calcarenites and marls, the proportion of the latter gradually increasing upward (Figs 3b, 4b). The planktic foraminiferal assemblage from the lower division includes the species Pr. uncinata and Morozovella angulata, which indicate the middle Danian biozones P1c (upper part), P2 and P3a (lower part) of Wade et al. (2011). The occurrence of Igorina pusilla in the middle division already indicates the late Danian biozone P3a, while the appearance of Globanomalina pseudomenardii near the top of the upper division demonstrates the Selandian biozone P4b (Fig. 3b).

The grey beds unit is $\sim 130 \mathrm{~m}$ thick, with gradational lower and upper boundaries, and it includes the ELPE and PETM hyperthermals (Figs 3b, 4c). The unit is principally composed of grey marls that intercalate a low proportion of calciturbidites, marly limestones and red marls. The calciturbidites appear randomly distributed throughout the succession, generally as isolated beds $\leq 15 \mathrm{~cm}$-thick, with Tbc or Tc Bouma sequences. The red marls and the limestones respectively occur within, or just above, the ELPE and PETM hyperthermals (Fig. 3b).

The upper red beds unit consists of an irregular alternation of red marls and limestones, with random intercalations of calciturbidites (Figs 3b, 4d). The unit has two main outcrops, one situated at the head of the La Leña ravine, capping the main section, and the other along the right hand margin of the Río Gor, in the foot wall of the thrust fault (Figs 3a, 4d). The preserved thickness of the unit in the La Leña ravine is $40 \mathrm{~m}$, as the succession is truncated by Pliocene alluvial conglomerates (Fig. 3b). The upper part of the outcrop is not accessible, and samples could only be collected in its lower and middle parts (Fig. 3b). The uppermost three samples collected contain Morozovella aragonensis, M. gracilis, Globanomalina indiscriminata, Acarinina pseudotopilensis, and forms akin to M. caucasica and $A$. bullbrooki. This planktic foraminifera association, and the absence of Turborotalia frontosa, indicate the lower part of the A. bullbrooki biozone of Orue-Etxebarria et 

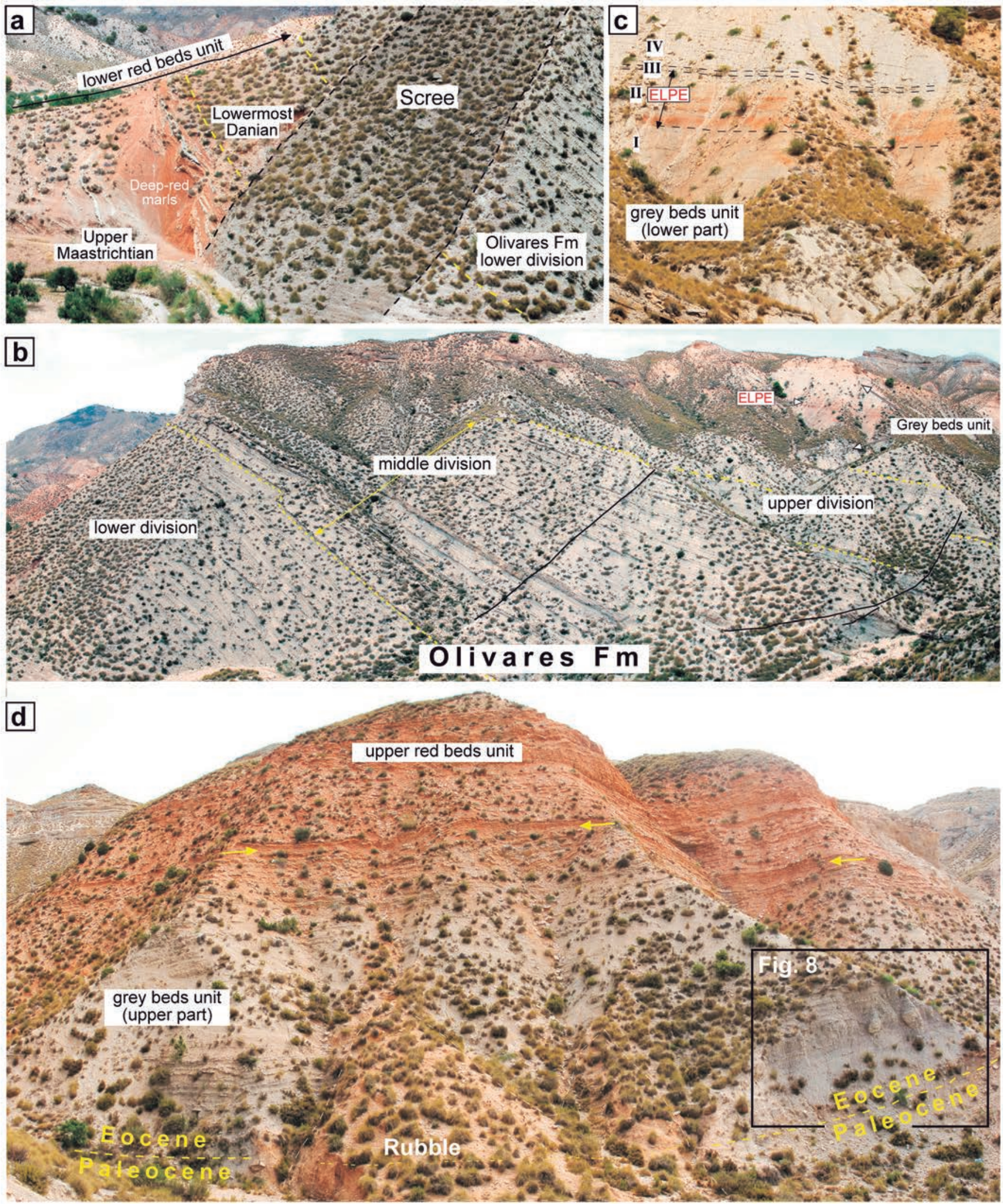

Figure 4. Field view of the lithostratigraphic units of the Río Gor section. a) Lower red beds unit (uppermost Maastrichtian-lower Danian). b) A complete view of the three divisions of the Olivares Formation (Danian-lower Selandian), and the lower part of the grey beds unit. c) Field view of the ELPE hyperthermal interval intercalated in the lower part of the grey beds unit (location in b). d) Upper part of the grey beds unit and of the overlying upper red beds unit, with yellow arrows indicating a prospective Eocene hyperthermal. 
al. (2006), which approximately corresponds to the late Ypresian E6/E7a of Wade et al. (2011). It is suspected, therefore, that the non-accessible upper part of the La Leña ravine outcrop may belong to the Lutetian. In any case, as reported by Pujalte et al. (2012), the $\sim 40 \mathrm{~m}$ thick segment of the upper red beds unit exposed in the right margin of the Río Gor outcrop includes the species T. frontosa A. praetopilensis, M. gorrondatxensis, Guembelitrioides nuttalli and Globigerinateka micra, which confirm the early Lutetian E7b and E8 biozones of Wade et al. (2011). Based on that information, the upper red beds unit as a whole can be confidently ascribed to the middle Ypresian/ lower Lutetian.
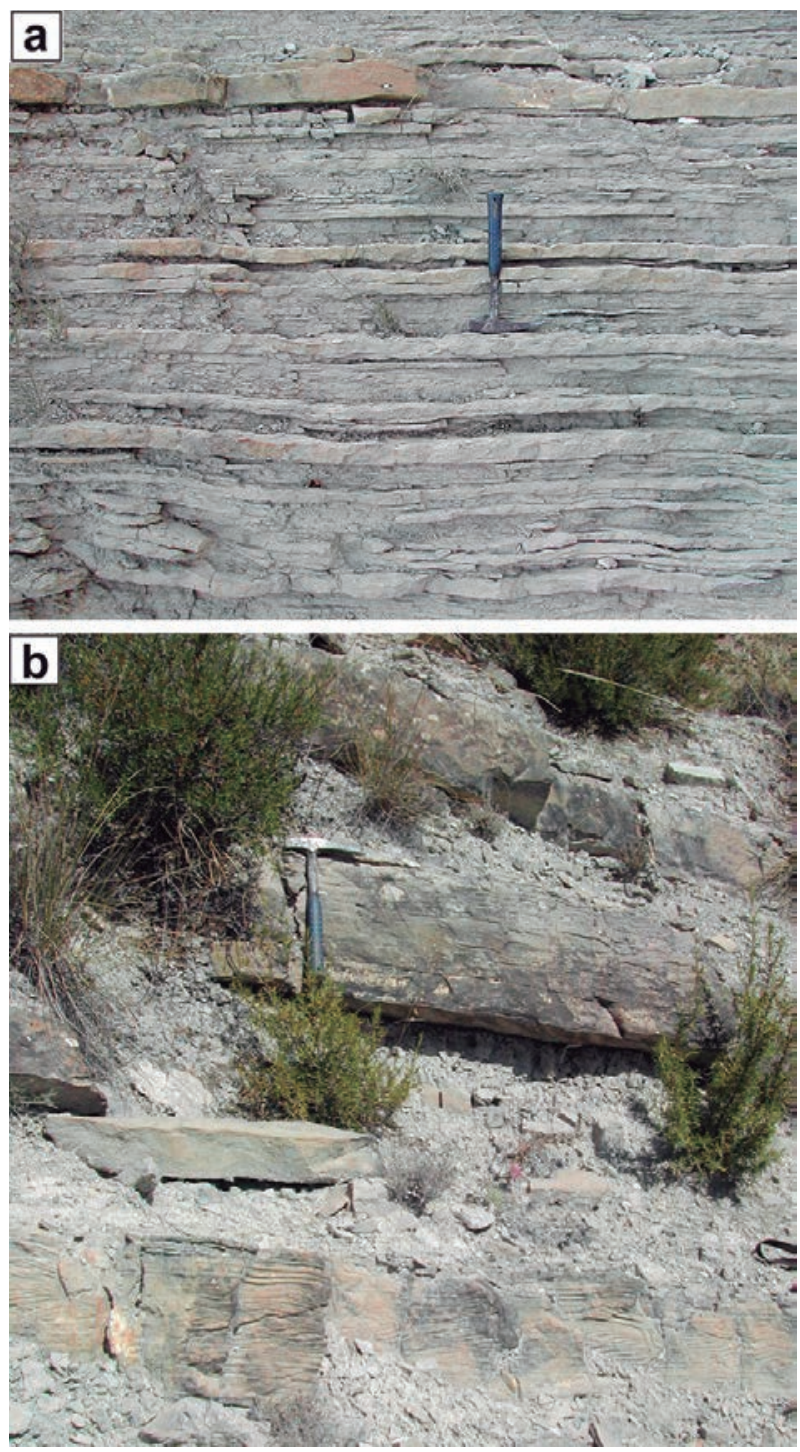

Figure 5. Close-up of the two main types of facies of the Microcodium-rich Olivares Formation. a) Thin-bedded calcarenites. b) Thick-bedded calciturbidites.

\subsection{Trace fossils}

The preliminary ichnological analysis carried out in the Paleocene deposits of the La Leña ravine segment of the section (Olivares Formation and lower-middle parts of the grey beds unit) revealed a trace fossil assemblage of moderate diversity, with 19 ichnogenera; some ichnospecies have been characterized. Recognized, in alphabetic order are Belorhaphe, Chondrites, Helminthopsis, Helminthorhaphe, Multina, Nereites, Ophiomorpha, Paleodictyon, Parahaentzscheliana, Phycodes, Phymatoderma, Planolites, Polykampton, Protopaleodictyon, Scolicia, Taenidium, Thalassinoides, Urohelminthoida and Zoophycos. Below a summarized description is given (see Uchman, 1995, 1998, 1999 for an extensive discussion of the ichnotaxa).

Belorhaphe shows horizontal structures with fine, angular zigzag second order meanders, which are thicker around points of curvature, and short lateral protrusions extending from the curves.

Chondrites (Fig. 6i) occurs in variable-oriented sections as oval spots or straight or slightly curved bars, showing in some cases tree-like branching. Different size structures could be related with the ichnospecies $C$. targionii (Brongniart, 1828), for the larger forms, and C. intricatus (Brongniart, 1828), for the smaller ones.

Helminthopsis is registered as simple, unbranched horizontal, elongated internally unstructured, cyclindrical tubes with curves, windings, or irregular open meanders.

Helminthorhaphe forms nonbranching burrows with only one order of smooth systematic meanders of very high amplitude, usually preserved as hypichnial semi-relief strings (Uchman, 1995).

Multina minima (Uchman, 2001) (Fig. 6d) occurs as a very irregular hypichnial net preserved in full relief, showing several swellings, undulations, small meanders and overlaps of string within the same structure. For discussion see Uchman (2001).

Nereites (Fig. 6g) is a horizontal, winding to regularly meandering trace composed of a median back-filled tunnel enveloped by an even to lobate zone of reworked sediment (Uchman, 1995).

Ophiomorpha (Fig. 6j) forms simple to complex burrow systems lined with agglutinated pelletoidal sediment (Uchman, 1995).

Paleodictyon (Fig. 6e) appears as a three-dimensional burrow system with a horizontal net composed of regular to irregular hexagonal meshes and vertical outlets (see Uchman, 1995).

Parahaentzscheliana (Fig. 6c) is observed as a group of numerous oval to circular pits more or less regularly distributed.

Phycodes corresponds to a horizontally bundle burrow consisting of a single or a few main branches that give rise distally to numerous free branches. 
Phymatoderma forms horizontal to subhorizontal trace fossils, straight to slightly curved tunnels, with more or less regular branches spreading out from one point. Sometimes tunnels show palmate terminations.
Planolites is represented by unlined, horizontal to oblique, straight to tortuous, simple, flattened cylinders of variable dimensions and configurations.

Polykampton (Fig. 6f) occurs as structures having numerous curved lobes with arcuate menisci alternately originating from a twisted axis.
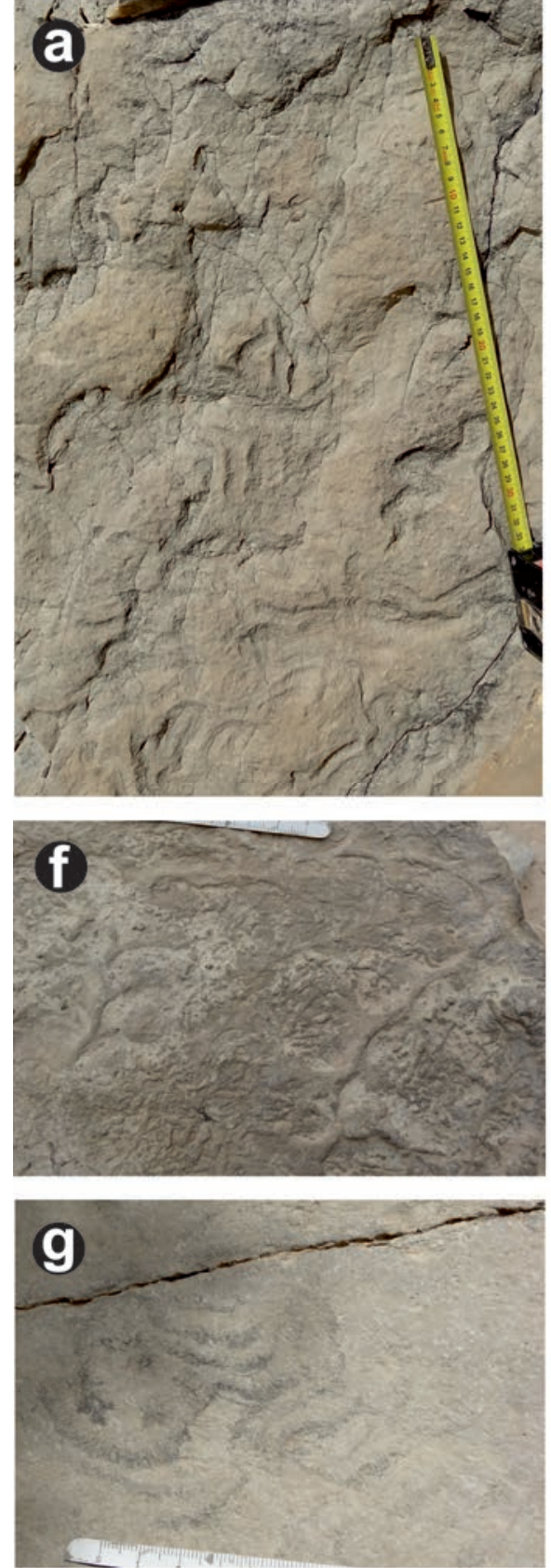
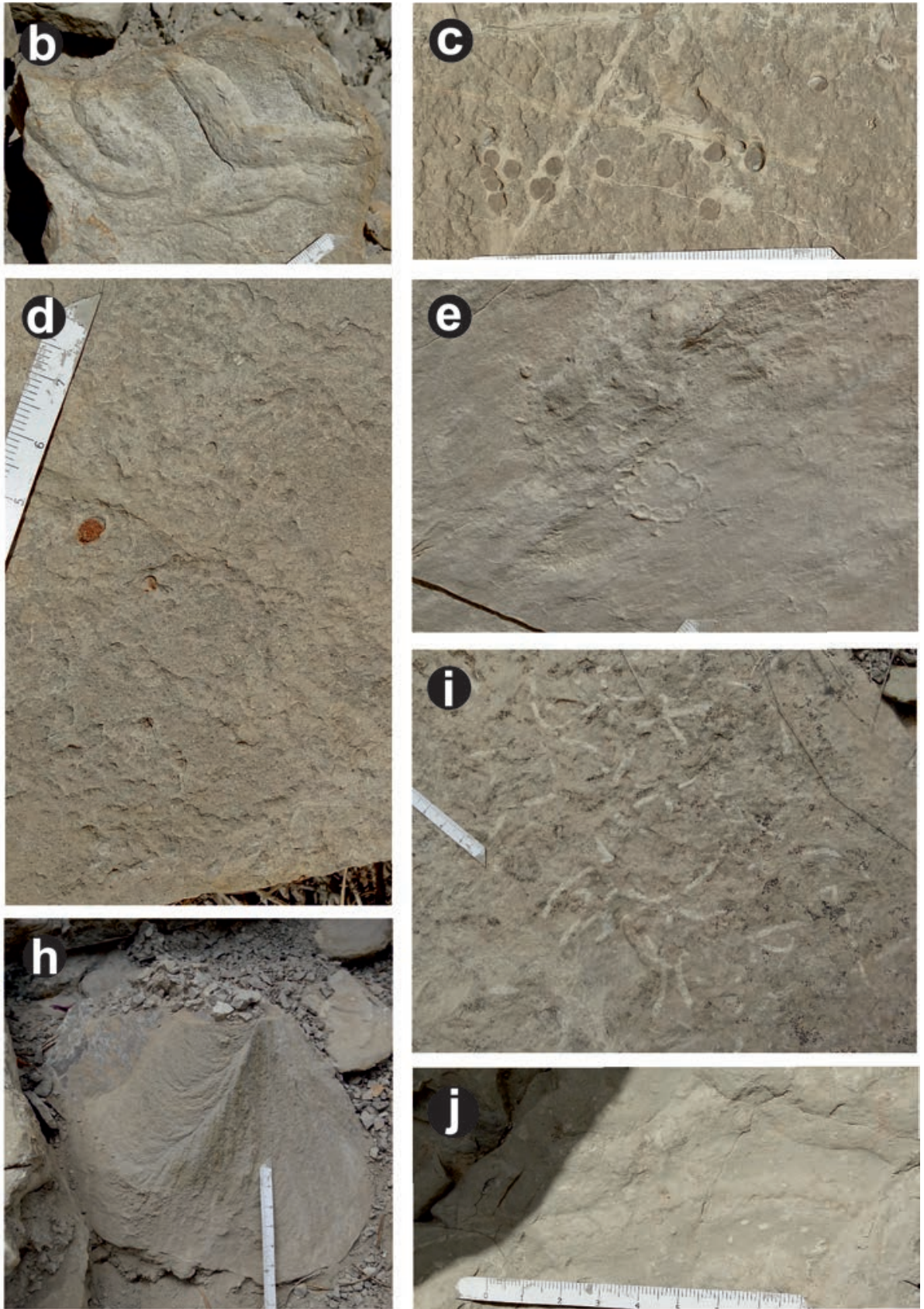

Figure 6. Trace fossils in the Paleocene segment (Olivares Formation and lower part of the grey beds unit) of La Leña ravine. a) Scolicia showing winding, meandering bilobated back-filled burrows. b) Scolicia vertebralis as hypichnial, semicircular winding ridge with a single central string. c) Parahaentzscheliana, showing a group of numerous circular pits more or less regularly distributed. d) Multina minima, as very irregular hypichnial net, showing several swellings, undulations, and small meanders. e) Paleodictyon, as three-dimensional burrow system with a horizontal net composed of irregular hexagonal meshes. f) Polykampton having curved lobes with arcuate menisci alternately originating from a twisted axis. g) Nereites, as horizontal, winding to regularly meandering with a median back-filled tunnel enveloped by reworked sediment. h) Zoophycos as a shaped spreite structures, showing a vertical orientation. i) Chondrites showing horizontal oval spots or straight/slightly curved bars. j) Ophiomorpha showing agglutinated pelletoidal sediment. 
Protopaleodictyon is registered as wide meanders having more or less regular second-order meanders, in cases with appendages branching from the apex of the second-order meanders.

Scolicia (Fig. 6a) appears as simple, winding, meandering to coiling bilobated or trilobated back-filled burrows with two parallel, locally discontinuous, sediment strings along the lower side. In some cases the ichnospecies Scolicia vertebralis (Ksiazkiewicz, 1977) (Fig. 6b) is differentiated as hypichnial, semicircular winding ridge with a single central string.

Taenidium is observed as horizontal to oblique, tubular meniscate structures.

Thalassinoides occurs as straight, horizontal to oblique flattened cylinders, showing $\mathrm{Y}$ and T-shaped branches, with smooth burrow margins.

Urohelminthoida forms burrow system preserved usually as deep, hypichnial meanders with lateral appendages protruding outwardly from the curved segments of the meanders.

Zoophycos (Fig. 6h) occurs as variably shaped spreite structures comprising numerous small protrusive roughly $\mathrm{U}$ - or J-shaped burrows of variable size and orientation. Most of the burrows are horizontal to subhorizontal, though occasional vertical forms have been registered.

In general, from bottom to top of the studied succession, variations in composition and relative abundance of ichnotaxa can be envisaged. Thus, preliminary analysis of the stratigraphic distribution reveals: a) a continuous record from the Olivares Formation to the grey beds unit of particular ichnotaxa such as Chondrites and Zoophycos, b) a higher abundance of Scolicia in the lower part of the Olivares Formation and decreasing upward, and c) the local record of Paleodictyon and Nereites in the lower and middle parts of the Olivares Formation, which seems to be absent in the grey beds unit.

\subsection{The Selandian/Thanetian interval and the ELPE}

\subsubsection{Background information}

The ELPE was first recognized by Petrizzo (2005) around the middle/late Paleocene (= Selandian/Thanetian; S/ Th) at Shatsky Rise in the NW Pacific Ocean. The event was subsequently documented in land-based deep marine successions (e.g., Bernaola et al., 2007, in the Zumaia section of the Basque Basin, N Spain; Coccioni et al., 2012, in the Contessa Valley, Gubbio, Italy) and in a terrestrial succession of Argentina (Hyland et al., 2015). These findings are a proof of the global impact of the event. At Shatsky Rise, the ELPE is recorded by a layer 5-25 $\mathrm{cm}$ thick of dark brown clay-rich calcareous nannofossil ooze situated on the lower part of the planktic foraminiferal
Zone P4 and just above the first occurrence of the nannolith Heliolithus kleinpellii, a marker of the base of the NP6 biozone of Martini (1971).

At the Zumaia section the ELPE is registered within the Itzurun Formation, an $80 \mathrm{~m}$-thick unit of alternating marls and limestones (Baceta et al., 2004). The ELPE occurs within a $4.5 \mathrm{~m}$-thick interval situated about $26 \mathrm{~m}$ from the base of the formation, through which the carbonate content first gradually decreases and then increases to background levels, the drop in carbonate being reflected by recessive strata in the cliff face (Fig. 7a). The minimum carbonate content $(<30 \%)$ is recorded in a $25 \mathrm{~cm}$-thick clayey layer, the core of the ELPE (figure 2 in Bernaola et al., 2007). The Global Stratotype Section and Point of the Thanetian Stage is situated about $2.8 \mathrm{~m}$ above this clayey layer (Fig. 7a; Schmitz et al., 2011). The ELPE is thus a good criterion to approximate the Selandian/Thanetian boundary.

In addition to this lithological change, the ELPE is recorded by a small isotope anomaly and by changes in the foraminiferal assemblages. Accordingly, Schmitz et al. (1997) demonstrated a rapid increase from $0.6 \%$ to $2.5 \%$ in $\delta^{3} \mathrm{C}$ values across the lower Selandian, an escalation that reaches peak values of 3.1\% at the lower Thanetian (Fig. 7b). The trend to more positive values, however, is temporarily reversed around the ELPE interval (Fig. 7b), a decline documented in detail by Bernaola et al. (2007; figure 2), who reported a minimum value of $1.2 \%$ at the core of the event.

The foraminiferal changes include a decrease in the test size of planktic specimens and a decrease in the planktic/ benthic ratio to a minimum at the core of the ELPE, facts attributed to an ecological disruption during the event (Bernaola et al., 2007; figure 4).

\subsubsection{The Selandian/Thanetian interval at the Rio Gor Section}

At the Río Gor section, the S/Th interval occurs within a segment of the grey beds unit in which four lithological intervals are readily recognized (Figs 4b-c, 7c), namely:

Interval I ( $>10 \mathrm{~m}$-thick), exclusively represented by medium-grey marls.

Interval II (9 m-thick) also composed of marls, mostly of red colours, but also greenish and yellowish. This variety of colours gives a characteristic banded aspect to the interval and allows its subdivision in three parts (II.1, II. 2 and II. 3 in Fig. 7c).

Interval III ( $1 \mathrm{~m}$-thick), made up of light-grey limestones separated by thin marly interbeds.

Interval IV (> $8 \mathrm{~m})$, consisting of alternating light-grey marls and limestones.

The planktic foraminiferal assemblage of 26 samples collected in this segment (distribution in Fig. 7c) includes the species Igorina albeari, I. pusilla, I. laevigata, Gl. pseudomenardii, Gl. ehrenbergi, Morozovella occlusa, 


\section{a ZUMAIA SECTION}
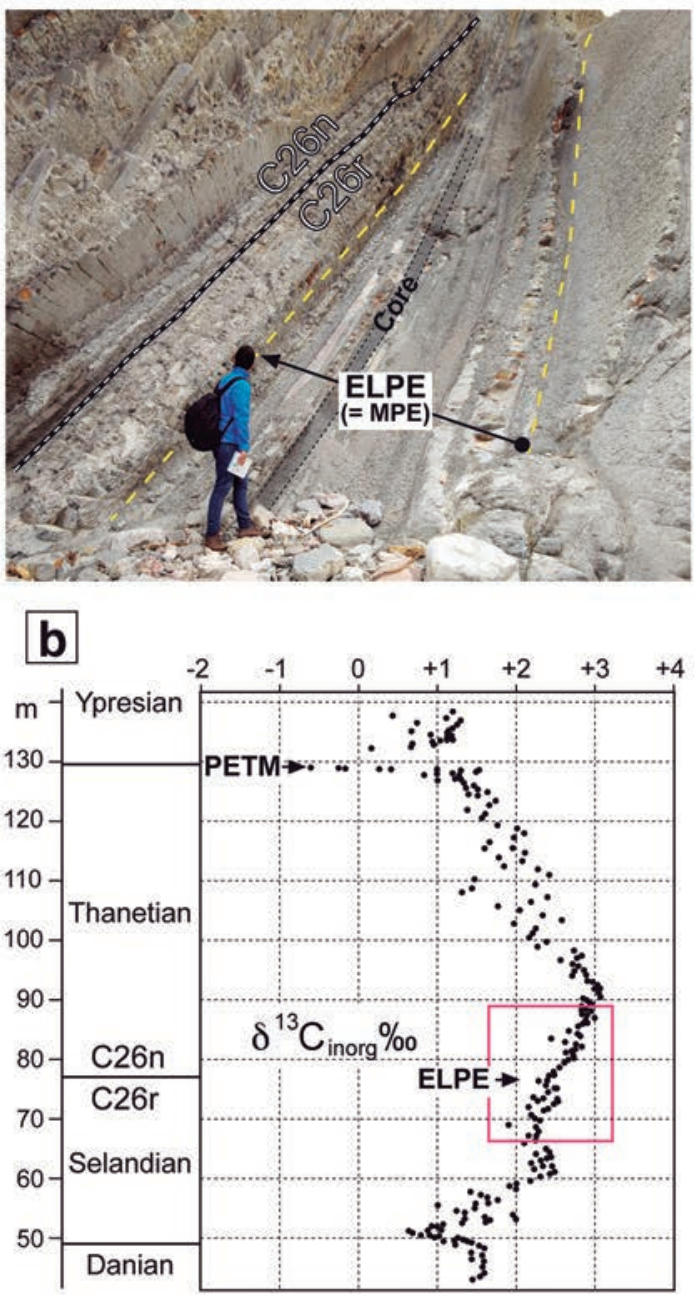

RÍO GOR SECTION

$$
\delta^{13} \mathrm{C}_{\text {org }} \%
$$

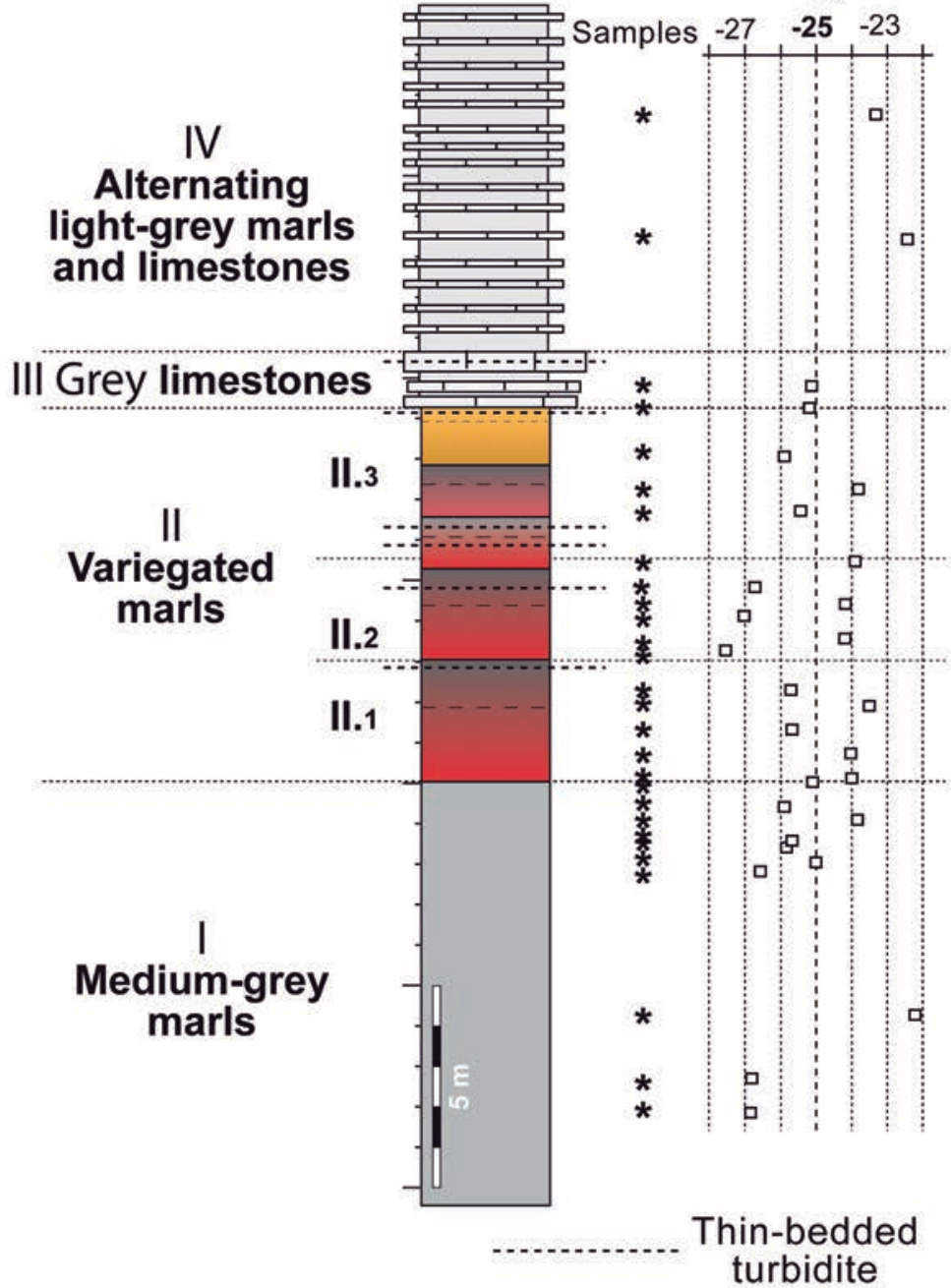

Figure 7. a) Field view of the ELPE hyperthermal interval at the Zumaia section, Basque Basin (after Bernaola et al., 2007). b) Whole-rock carbon isotopic curve spanning the upper Danian to the lower Ypresian at Zumaia (modified from Schmitz et al., 1997). c) Detailed litholog and organic carbon isotopic profile of the ELPE hyperthermal interval at the Río Gor section.

M. velascoensis, M. angulata, M. conicotruncata, M. acutispira, Subbotina velascoensis, and Acarinina subsphaerica, which denotes a mid-Paleocene age. The calcareous nannofossil assemblage of the same samples comprises, among others, Fasciculithus tympaniformis, Toweius eminens, T. pertusus, Coccolithus pelagicus, Ericsonia subpertusa, Sphenolithus moriformis, Ellipsolithus macellus, and the appearance of the genera Discoasteroides and Heliolithus. Such an assemblage is indicative of the upper part of Zone NP5 and Zone NP6.

Variations in the character of the foraminiferal associations across the studied segment were observed, which provide additional key information. Thus, planktic specimens in intervals I, III and IV account for more than $95 \%$ of the total foraminiferal assemblage. The planktic foraminifers are still dominant in intervals II.1 and II.3, but notably smaller in size than in the underlying and overlying intervals. Most significantly, in interval II.2 the planktic and benthic foraminifers occur in a similar proportion, the assemblage of benthic foraminifers being moderately diverse but low in evenness, being characterized by the dominance of small abyssamminids.

The lowest occurrence of the calcareous nannofossil H. kleinpellii, marking the base of Zones NP6 and CP5 (Martini, 1971; Okada \& Bukry, 1980), was found at the bottom of interval II.2, which is further characterized by the occurrence of $D$. bramlettei, $S$. anarrhopus and Sphenolithus sp.1 of Agnini et al. (2009). The isotopic values show significant scatter throughout the studied segment, with $\delta^{13} \mathrm{C}_{\text {org }}$ values ranging between -22.2 and $-27.5 \%$, the most negative ones $(-27.5 \%)$ occurring in interval II.2 (Fig. 7c). 


\subsection{The Paleocene/Eocene interval and the PETM}

\subsubsection{Background information}

The PETM is the most prominent and extensively studied early Cenozoic hyperthermal, and the first to be discovered (e.g., Koch et al., 1992; Thomas \& Zachos, 2000; Sluijs et al., 2007; Zachos et al., 2008; McInerney \& Wing, 2011). It is characterized by a global temperature increase of $\sim 5-8$ ${ }^{\circ} \mathrm{C}$, caused by a massive injection of light carbon into the ocean-atmosphere reservoirs, an injection recorded in both marine and terrestrial environments by a negative carbon isotope excursion (CIE). The global warming caused faunal and floral changes in terrestrial and marine ecosystems, including the extinction of $40-60 \%$ of deep-sea benthic foraminifera (benthic foraminiferal extinction event, BEE) (e.g., Thomas \& Shackleton, 1996; Thomas, 2007; Alegret et al., 2009a), and transient biotic changes in other organisms, including calcareous nannofossils and planktic foraminifera (e.g., Kelly et al., 1998; Bralower, 2002; Gingerich, 2003; Wing et al., 2005; Molina, 2015). The light carbon injection also caused ocean acidification (e.g., Zachos et al., 2005) and acceleration of the hydrologic cycle (e.g., Schmitz \& Pujalte, 2007; Pujalte et al., 2015a, 2016; Giusberti et al., 2016). After several years of scrutiny of the P/E interval, the onset of the CIE was formally adopted as the main criterion to define the base of the Eocene (Aubry et al., 2007), the biotic and environmental changes associated with the PETM providing additional correlation criteria.

\subsubsection{The Paleocene/Eocene interval at the Rio Gor section}

At the Río Gor section, the study of planktic foraminifera from 11 samples (BL-1 to BL-11) served to constrain the $\mathrm{P} / \mathrm{E}$ interval to a $20 \mathrm{~m}$-thick segment of the grey beds unit (Figs 4d, 8a). This segment comprises six different lithological intervals, namely:

Interval I ( $>5 \mathrm{~m})$ composed of medium-grey marls.

Interval II $(0.9 \mathrm{~m})$, made up of deep-red marls capped by a $3 \mathrm{~cm}$-thick calciturbidite layer.

Interval III (3.65 m), mainly comprising light-grey marls and marly limestones.

Interval IV $(1.55 \mathrm{~m})$, formed by light-grey limestones with intercalated thin-bedded calciturbidites.

Interval V $(5.5 \mathrm{~m})$, characterized by alternating marls and marly limestones with a few prominent intercalated calciturbidites.

Interval VI ( $>3 \mathrm{~m})$, mainly composed of light-red marls.

The most characteristic planktic foraminifera species in samples from interval I (BL-11 to BL-4) are Morozovella occlusa, $M$. velascoensis, $M$. subbotinae, $M$. marginodentata, M. acuta, M. aequa, Subbotina linaperta, S. velascoensis, Acarinina nitida, A. pseudotopilensis, Gl. pseudomenardii, Gl. imitata and Chiloguembelina wilcoxensis. Such an assemblage is indicative of the upper part of the Acarinina soldadoensis biozone of OrueEtxebarria et al. (2004), equivalent to the late Paleocene Zone P4c of Wade et al. (2011). The composition of samples from interval V (BL-8 to BL-11) is similar, except that $G l$. pseudomenardii is absent and they contain $A$. wilcoxensis and Planorotalites pseudoscitula. These facts, together with the permanence of $M$. velascoensis and $M$. occlusa, demonstrate the early Eocene Zone $A$. wilcoxensis of Orue-Etxebarria et al. (2004), equivalent to E2 Zone of Wade et al. (2011).

Carbon isotope analyses of dispersed organic matter were carried out in three samples. The values of two, BL-2 and BL-3, were respectively $-24.5 \%$ and $-24.3 \%$, whereas in two replicate analyses of sample BL-5 the values were $-26.2 \%$ and $-26.5 \%$ (Fig. 8a). These values entail a negative excursion of $\sim 2 \%$ at the base of interval II.

The benthic foraminiferal assemblages in the four samples of interval I (BL-1 to BL-4) are diverse and contain abundant Paleocene cosmopolitan species with heavily calcified tests. A major turnover is observed at sample BL-5 from Interval II, where the highest occurrence of several benthic foraminiferal species, including Stensioeina beccariiformis, Angulogavelinella avnimelechi and Marssonella oxycona, is recorded.

The diversity, but not the abundance, of the assemblages of benthic foraminifera decreases at sample BL-5, characterized by the dominance of small-sized species as Oridorsalis umbonatus, Nuttallides truempyi and Anomalinoides. In turn, the abundance of planktic foraminifera decreased at this sample. The benthic foraminiferal assemblages do not fully recover over the next and final part of the studied segment (samples BL-6 to BL-11).

The eleven BL samples were also analyzed for calcareous nannofossils. The calcareous nannofossil events defined by Martini (1971) were used, demonstrating that the studied segment spans from Zones NP9 to NP10. To define the base of Zone NP10, characterized by the base of Rhomboaster bramlettei, we followed the definition of Bybell \& Self-Trail (1995), who included Rhomboaster cuspis of many authors with $R$. bramlettei. In addition, we adopted the taxonomic remarks of Angori \& Monechi (1996) and Angori et al. (2007), who differentiated three morphotypes: $R$. bramlettei "short arms," R. bramlettei "long arms," and $R$. bramlettei var. T.

Calcareous nannofossil assemblages vary from common to abundant in the all the studied samples, but preservation is poor. Cretaceous reworking, while present throughout the studied segment, is rare in most samples but common in sample BL-8. The upper Paleocene nannofossil assemblages in interval I (samples 
BL-1 to BL-4) are mainly composed of Coccolithus pelagicus, Toweius pertusus, Fasciculithus tympaniformis, Sphenolithus, Discoaster multiradiatus, and less commonly Zygrhablithus bijugatus. Rare rhombohedrals were present from the base of the sections.

A major turnover is observed at sample BL-5, where $R$. bramlettei "s. a" and "l. a" have their lowest occurrence (Fig. 8a). In the same level, an increase in abundance and diversity of Discoaster is seen, with the occurrence of peculiar asymmetrical forms as Discoaster araneus and
D. anartios. The increase in abundance of Discoaster mainly concerns $D$. multiradiatus as well as $D$. nobilis and $D$. delicatus. Within this level, a drop in abundance of Fasciculithus and Zygrhablithus bijugatus and an increase of Thoracosphaera (dinoflagellate cysts) are observed. Discoaster araneus and D. anartios "excursion taxa" are present in the following samples up to BL7. These forms usually characterize the CIE interval and disappear where $\delta^{13} \mathrm{C}$ returns to pre-excursion values (Angori et al., 2007). In the upper part of the studied interval (samples BL9 and
Río Gor section (Subbetic Zone)

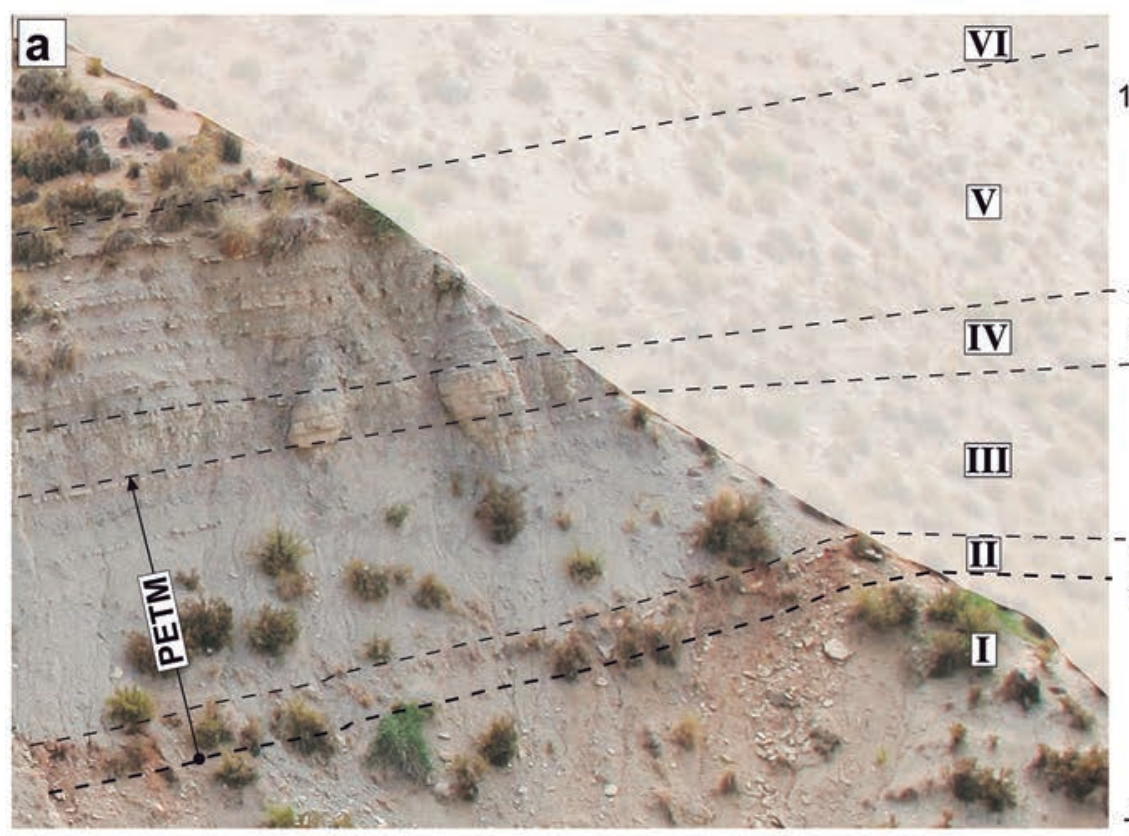

b

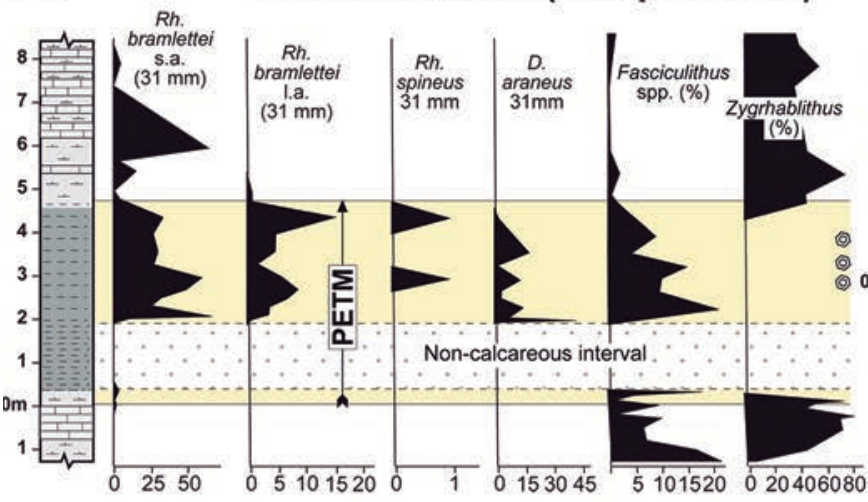

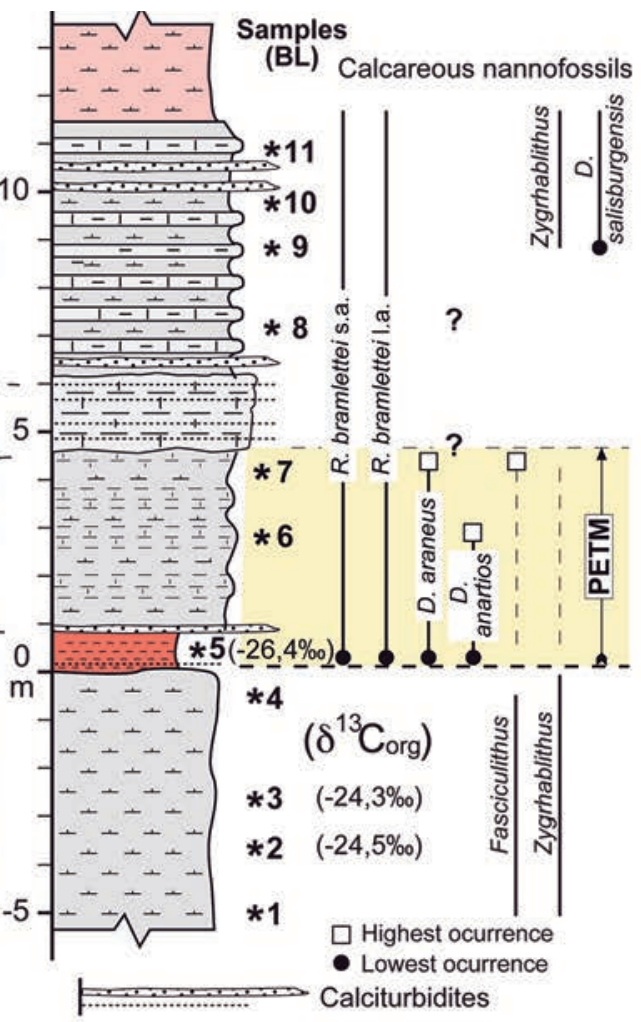

Alamedilla section (Subbetic Zone)

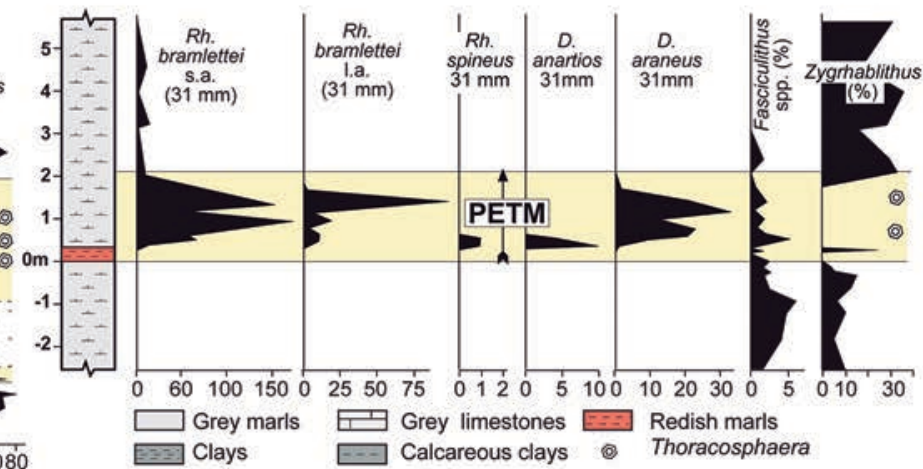

Figure 8. a) Field view, litholog, location of samples and ranges of selected calcareous nannofossils across the P-E interval in the Río Gor section. The isotopic composition of organic carbon of samples 2, 3 and 5 is shown in parenthesis. b) Relative abundance of selected calcareous nannofossils across the P-E interval in the Zumaia and Alamedilla sections (modified from Figs 2 and 3 of Angori et al., 2007). Percentages of Zygrahablithus and Fasciculithus are calculated from the non Toweius spp $+C$. pelagicus fraction. For other species, the number of specimens in a 31-mm-long track is represented. Explanation in text. 
BL11) Discoaster diastypus, D. salisburgensis and D. binodosus have their lowest occurrences. Zygrhablithus bijugatus reappears and increases considerably in the uppermost part of the segment. These major changes in calcareous nannofossil assemblages are in agreement with what has been documented at the P/E boundary interval in the Zumaia and Alamedilla sections (Fig. 8b) and in several other Tethyan sections, including Caravaca (Spain) and Contessa (Italy).

\subsection{A prospective Eocene hyperthermal}

Towards the lower part of the upper red beds unit there occurs a prominent interval of recessive strata (Fig. $4 \mathrm{~d}$, arrowed), most likely indicative of a lower calcium carbonate content than in the bulk of the unit, a telltale feature of hyperthermal events. To corroborate that possibility, three samples were collected, one from just below the recessive interval and the other two from inside it (uppermost 3 samples in Fig. 3b), which were analyzed for calcareous plankton and planktic foraminifera.

Calcareous nannofossils are abundant and diversified in the three samples, yet not well preserved. Among others, the assemblages include Sphenolithus radians, Tribrachiatus orthostylus, Discoaster barbadiensis, D. lodoensis and very rare Girgisia cf gammation. According to a recent paper (D'Onofrio et al., 2016) the presence of these taxa would suggest the CNE3 Zone, which approximately correlates with the E4 Zone of Wade et al. (2011), a zone that contains the hyperthermals ETM2, H2 and I1. The absence of Tribrachiatus contortus suggests the CP9b Zone and, consequently, the ETM2. However, the presence of Discoaster lodoensis and very rare Girgisia cf. gammation, as well as the data on planktic foraminifera mentioned above (chapter 4.1), suggest a younger hyperthermal. Clearly, more biostratigraphic and isotopic data will be necessary to resolve this issue.

\section{DISCUSSION}

\subsection{Constraining the ELPE and the PETM at the Río Gor Section}

Calcareous nannofossil, foraminiferal and isotopic information indicate that interval II of the S/Th interval of the Río Gor section records the ELPE, with interval II. 2 representing the core of the event. In effect, as at Shatsky Rise, H. kleinpellii is registered in the Río Gor section just below interval II.2. Also, the decrease in size of planktic foraminifers along with the reduction of the planktic/benthic foraminiferal ratio across interval II are comparable to those observed in the Zumaia section. Most significantly, in interval II.2 benthic foraminifers account for up to $50 \%$ of the total foraminiferal population, their assemblages being moderately diverse but low in evenness, as they are characterized by the dominance of small abyssamminids known to peak after the PETM and other Eocene hyperthermals (e.g., Thomas, 2007). Further, despite the scatter in isotopic values, the typical early to late Paleocene gradual rise in $\delta^{13} \mathrm{C}$ can be recognized, and occurrence of the most negative values $(-27.5 \%)$ in interval II.2 reinforces its attribution to the core of the ELPE.

The Río Gor section probably contains the most expanded record of the ELPE reported to date, with interval II.1 recording an initial period of stressed oceanic conditions, interval II.2 the climax of the event, and interval II.3 the gradual recovery to normal background conditions.

The negative excursion at the base of interval II of the $\mathrm{P} / \mathrm{E}$ segment of the section is of similar magnitude to that found at the onset of the PETM in the Zumaia section (e.g., Storme et al., 2012). Despite the low number of isotopic analyses, the occurrence of Rhomboaster, Discoaster araneus and $D$. anartios in sample BL-5 from interval II strongly suggests that the negative excursion records the onset of the CIE, as these calcareous nannofossil species characterize the basal $\mathrm{P} / \mathrm{E}$ boundary in many other sections (Fig. 8b).

The benthic foraminiferal record reinforces this conclusion. The highest occurrence of Stensioeina beccariiformis, Angulogavelinella avnimelechi, Marssonella oxycona and other species clearly indicate the BEE, which has been recorded in coincidence with the onset of the CIE that marks the base of the PETM (e.g., Tjalsma \& Lohman, 1983; Thomas, 1998). Further, the decrease in the abundance of planktic foraminifera in sample BL-5 could be related to the documented widespread $\mathrm{CaCO}_{3}$ dissolution at deep-sea settings during the PETM, which led to a drop in ocean $\mathrm{pH}$ and shoaling of the CCD (e.g., Dickens et al., 1997; Zachos et al., 2005). An increase in agglutinated foraminifera has been recorded in other sections worldwide, including the nearby Alamedilla section (Alegret et al., 2009b, 2010), being related to the effects of carbonate dissolution triggered by the shoaling of the CCD. This increase in agglutinated foraminifera is, however, not recorded at the Río Gor section, most likely because of the lower resolution of this study as compared to the Alamedilla section, where the increase in agglutinated foraminifera or disaster fauna was recorded over an interval of $20 \mathrm{~cm}$ just above the BEE. In fact, the benthic foraminiferal assemblage at sample BL-5 shows similarities to the opportunistic benthic faunas recorded at the Alamedilla section after the disaster fauna (Alegret et al., 2009b, 2010).

Finally, it is worth pointing out that both the ELPE and the PETM are capped by carbonate units, respectively 
by interval III at the $\mathrm{S} / \mathrm{Th}$ segment and by interval IV at the $\mathrm{P} / \mathrm{E}$ segment (Figs 7-8). These limestone units are tentatively interpreted to record the periods of enhanced carbonate accumulation documented in deep oceanic settings during the recovery phase of carbon cycle perturbations, a process called overshoot (e.g., Luo et al., 2016; Penman et al., 2016).

\subsection{Depositional depth of lower Paleogene reference sections of the Subbetic Zone}

The depositional depth of some of the lower Paleogene reference sections of the Subbetic Zone is somewhat controversial. For instance, Vera \& Molina (1999; figure $5 b)$ argued that the bulk of their Upper Cretaceous/Eocene comprehensive Capas Rojas Formation was passively deposited draping a faulted paleorelief at depths ranging from less than $200 \mathrm{~m}$ to about $1000 \mathrm{~m}$. Molina et al. (2006) postulate that the Microcodium-rich Majalcorón Formation, coeval to the Olivares Formation, was deposited in a shallow marine setting that eventually became emergent. Alegret et al. (2009b) concluded that during the P/E interval the Alamedilla section was placed at a lower bathyal depth (1000-2000 m).

Our estimation of the depositional depth of the Río Gor section is based on foraminiferal data and on ichnological information. The planktic/benthic foraminiferal ratio in most of the studied samples is very high $(\sim 95 \%)$, a clear indication of an open-marine setting. The mixed calcareous-agglutinated benthic foraminifera denote deposition above the $\mathrm{CCD}$, with calcareous foraminifers dominating the assemblages $(60-75 \%)$. Further, the assemblages contain common representatives of the bathyal and abyssal Velasco-type fauna (Berggren \& Aubert, 1975) namely Nuttallides truempyi, Stensioeina beccariiformis, Gaudryina pyramidata or Aragonia velascoensis, as well as other deep-water species such as Bulimina trinitatensis or Marssonella oxycona. The upper depth limit of some of the most abundant species at the $\mathrm{P} /$ E interval of the Río Gor section (e.g., B. trinitatensis, $N$. truempyi, S. beccariiformis) is located at 500-700 $\mathrm{m}$ depth. Shallow-water taxa (e.g., Angulogavelinella avnimelechi and Lenticulina species) that are common in sublittoral to upper bathyal depths are present, but they are less common and might be resedimented. These data suggest deposition in middle-lower bathyal conditions.

The trace fossil assemblage can be attributed to the Nereites ichnofacies, typical of deep-sea environments, with presence of Nereites and graphogliptids (e.g., Belorhaphe, Helminthorhaphe, Paleodictyon, Protopaleodictyon, and Urohelminthoida) (Uchman, 2009; Uchman \& Wetzel, 2011). Nereites ichnofacies represents a trace fossil assemblage common in basin-floor depositional environments, associated with a continuous and very slow sedimentation of pelagic and hemipelagic materials, interrupted by periodic turbiditic deposition. At the moment, for the case study, no differentiation of ichnosubfacies into the Nereites ichnofacies can be approached in terms of the different parts of a turbidite deposit, with Ophiomorpha rudis ichnosubfacies, mainly registered in thick-bedded sandstone of turbidite successions from channels or proximal lobes, Paleodictyon ichnosubfacies, from more sandy, medium-to-thin bedded flysch deposits, and Nereites ichnosubfacies, associated with the most distal part of the turbidite characterized by muddy distal flysch sediments. Registered variations in the trace fossil assemblage from the lower division of the Olivares Formation to the grey beds unit, in agreement with changes in facies, could reflect variations in hydrodynamic energy, substrate and/or organic matter content. These changes in palaeoenvironmental conditions are probably related to variations in sea-level dynamics registered in different parts of turbiditic depositional settings, as recently recognized for other Eocene to Miocene successions from the Pyrenees (Rodríguez-Tovar et al., 2010; Astibia et al., 2017) and the Betic Cordillera (see Rodríguez-Tovar et al., 2016, for a review of ichnological analyses of flysch successions in Spain).

\subsection{The Río Gor as a reference section}

The lower Paleogene succession is thicker and better exposed at the Río Gor section than at the Caravaca section. A detailed comparison between the two sections, however, is hindered by the fact that, to our knowledge, the only studies encompassing the whole lower Paleogene succession of the Caravaca section are those by Van Veen (1969) and Hillebrandt (1974), both of which are somewhat outdated.

The lower red beds unit has a similar representation at Alamedilla and Río Gor sections, including the hiatus at the K/Pg boundary and the uppermost Maastrichtian deepred marls (Figs 2b, 4a). Yet a comparison of the synthetic logs of the two units readily shows their lower Paleogene successions to be very different (Fig. 9). At Alamedilla, the Olivares Formation and a substantial part of the grey beds unit are missing, and the upper red bed unit is thicker and more complete at Río Gor (Figs 2b, 9).

The reason for the differences between these two sections is unclear. According to the scenario envisaged by Vera \& Molina (1999; figure 5b), the Alamedilla and Río Gor sections would have been deposited, during a tectonically quiet period, respectively on high and low parts of an inherited paleorelief. Alternatively, Pujalte et al. (2014a) suggested that the extensive lower red bed unit indicates tectonic quiescence during Upper Cretaceous/ early Danian times, but that the important thickness variation of the middle Danian to Selandian succession at 
Alamedilla and Río Gor (Fig. 9) may best be explained by differential subsidence driven by tectonic activity. The sharp lower boundary of the Olivares Formation at the Río Gor section, which implies a sudden input of land-derived calcarenites, would back the latter alternative.

Whatever the case, the expanded character of the Río Gor section, coupled with its accumulation in a deepmarine setting, come to suggest a rather complete lower

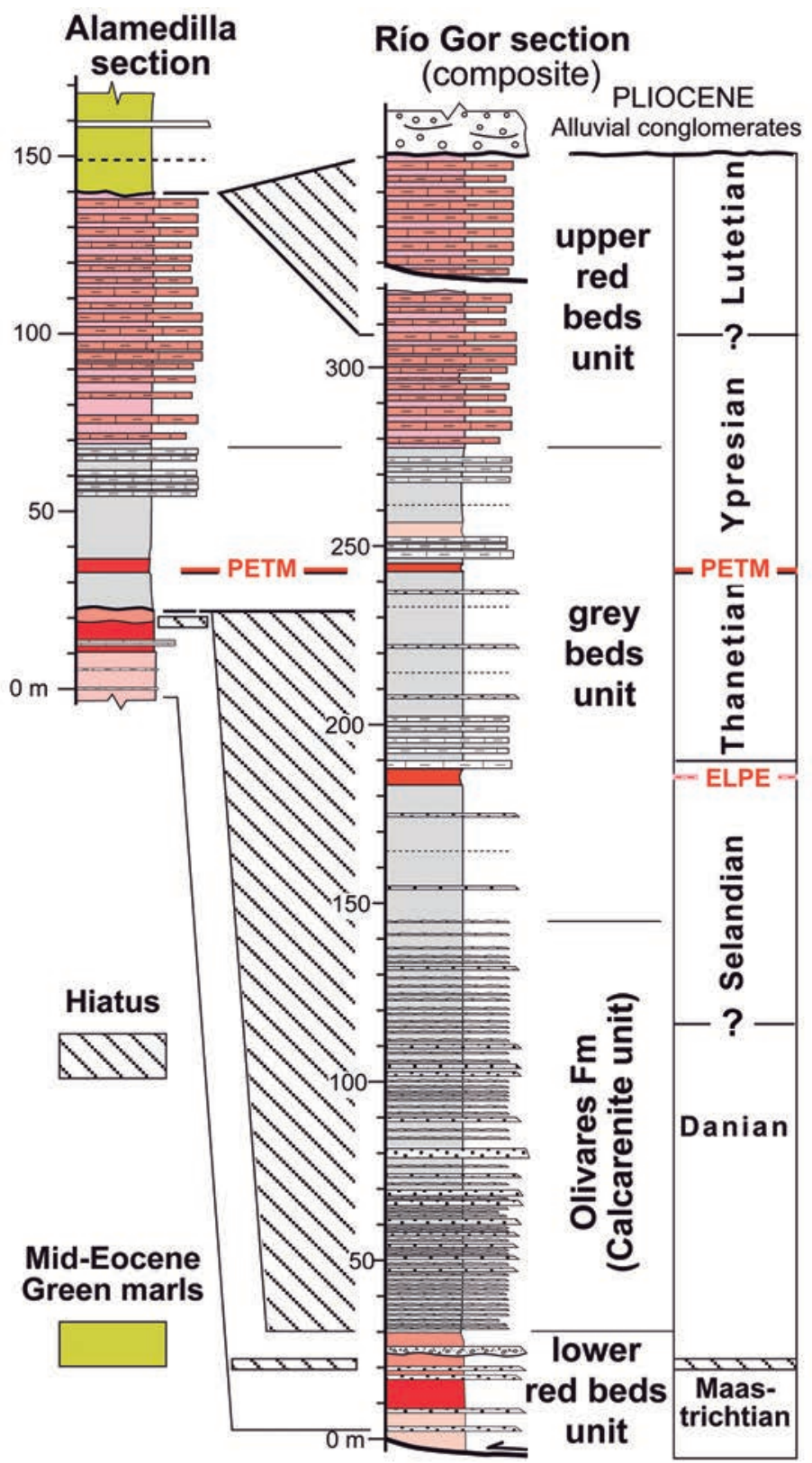

Figure 9. Correlation of the Alamedilla and Río Gor sections. To facilitate comparison, the Lutetian segment from the footwall of the thrust fault affecting the Río Gor section is drawn in its stratigraphic position. The middle Eocene green marls are only preserved in the Alamedilla section (explanation within text).
Paleogene stratigraphic record. Available information of planktic foraminifers supports that inference, with the exception of the $\mathrm{K} / \mathrm{Pg}$ hiatus since foraminiferal associations of successive samples have not revealed any biostratigraphically resolvable discontinuity. Clearly, the Río Gor section contains a more complete archive than any other coeval reference section so far reported in the Subbetic Zone, and thus offers greater opportunities for locating and studying early Paleogene hyperthermals. Nevertheless, more work is still necessary to exploit its possibilities.

\subsection{ELPE and PETM at the Río Gor and the Zumaia sections}

Inspection of the ELPE and the PETM at the Río Gor and the Zumaia sections reveals some common features together with significant differences. Both hyperthermals are typified by CIEs, a proof that their origins are linked to global carbon cycle perturbations. Furthermore, the end of both hyperthermals is marked by carbonate units, probably recording post-event overshoots, which are particularly prominent in the marly Río Gor record (i.e., interval III of the ELPE and interval IV of the PETM; Figs 7-8), but which are also observable at the Zumaia section (Fig. 7a).

The structures of the CIEs of these two hyperthermals are quite different, however. First of all, the one of the ELPE was of lesser magnitude than that of the PETM. Second, and more remarkably, the CIE of the ELPE developed gradually, its core occurring in both the Zumaia and Río Gor sections towards the middle part of the hyperthermal (Figs 7a-c), whereas the onset of the CIE of the PETM was rather abrupt in both sections (e.g., Schmitz et al., 1997; Storme et al., 2012; Fig. 8a). This fact suggests that the trigger of the carbon emissions of these two hyperthermals may have had different origins.

The lithological expressions of the PETM at the Zumaia and Río Gor sections are also very different. In the former section, the event is represented by a prominent non- to low-calcareous fine-grained siliciclastic unit intercalated within the otherwise hemipelagic succession (Fig. 8b). This siliciclastic unit has been attributed to enhanced seasonal precipitation during the PETM, with longer drier seasons and intensified flood events during wet seasons, with rivers delivering great volumes of siliciclastics to the basin and diluting the pelagic contribution (e.g., Schmitz et al., 2001; Pujalte et al., 2015a). In contrast, an increase in the percentage of carbonate is recognizable in the field at the Río Gor section during the PETM interval (Fig. 8a). This fact suggests that the environmental response to the climatic perturbation in the Subbetic Zone was quite different from that in the Basque Basin, whose exact nature still needs to be investigated. 


\section{CONCLUSIONS}

The Río Gor section contains the thickest and possibly the most complete lower Paleogene succession so far reported in the Subbetic Zone. The high planktic/benthic foraminiferal ratio $(\sim 95 \%)$ in most samples indicates an open-marine setting, the benthic foraminiferal assemblages indicate a marine environment that was probably deeper than 500-700 m, and trace fossil assemblages suggest a basin-floor setting. Both, the expanded character of the succession and the planktic foraminiferal information point to a rather continuous stratigraphic record, with the exception of a hiatus at the $\mathrm{K} / \mathrm{Pg}$ boundary, which seems to be widespread in the Subbetic Zone. The location of two major hyperthermals, the ELPE and the PETM, has been narrowly constrained, and an additional hyperthermal candidate has been pinpointed within the lower Eocene. The analysis in depth of these events, however, calls for further research efforts.

\section{ACKNOWLEDGEMENTS}

Research by VP, EA, SO and XO-E was supported by project CGL2015-65404-R MINECO/FEDER-UE, and Consolidated Research Group IT930-16; the fieldwork of FC was sponsored by a PES grant from the University of the Basque Country. The research of FR-T was financed by Project CGL2015-66835-P-UE (Secretaría de Estado de I+D+I, Spain), Research Group RNM-178 (Junta de Andalucía) and the Unidad Científica de Excelencia UCEPP2016-05 (University of Granada). The research of SM was supported by the University of Florence 60\% 2015. The suggestions of Eustoquio Molina, of an anonymous reviewer and of journal editor Julio Aguirre are greatly appreciated. We are also grateful to María Lema Grille (A Coruña) for the isotope analyses, and to the proprietors of the Cortijo del Royo for allowing access to the section through their private unpaved road.

\section{REFERENCES}

Agnini, C., Macrì, P., Backman, J., Brinkhuis, H., Fornaciari, E., Giusberti, L., Luciani, V., Rio, D., Sluijs, A. \& Speranza, F. 2009. An early Eocene carbon cycle perturbation at $\sim 52.5$ Ma in the Southern Alps: chronology and biotic response. Paleoceanography, 24, PA209; doi:10.1029/2008PA001649.

Alegret, L., Ortiz, S., Orue-Exteberria, X., Bernaola, G., Baceta, J.I., Monechi, S., Apellaniz, E. \& Pujalte, V. 2009a. The Paleocene-Eocene thermal maximum: new data on microfossil turnover at the Zumaia section, Spain. Palaios, 24, 318-328; doi: 10.2110/palo.2008.p08-057r.
Alegret, L., Ortiz, S. \& Molina, E. 2009b. Extinction and recovery of benthic foraminifera across the PaleoceneEocene Thermal Maximum at the Alamedilla section (Southern Spain). Palaeogeography, Palaeoclimatology, Palaeoecology, 279, 186-200; doi:10.1016/j. palaeo.2009.05.009.

Alegret, L., Ortiz, S., Arenillas, I. \& Molina, E. 2010. What happens when the ocean is overheated? The foraminiferal response across the Paleocene-Eocene Thermal Maximum at the Alamedilla section (Spain). Geological Society of America Bulletin, 122, 1616-1624; doi: 10.1130/B30055.1.

Angori, E. \& Monechi, S. 1996. High-resolution calcareous nannofossil biostratigraphy across the Paleocene/Eocene boundary at Caravaca (southern Spain). Israel Journal of Earth Sciences, 44, 197-206.

Angori E., Bernaola G. \& Monechi S. 2007. Calcareous nannofossil assemblages and their response to the Paleocene/Eocene Thermal Maximum event at different latitudes: ODP 690 Site and Tethyan sections. In: Large Ecosystem Perturbations: Causes and Consequences (eds Monechi, S., Coccioni, R. \& Rampino, M.R.). The Geological Society of America Special Paper, 424, p. 6985; doi: 10.1130/2007.2424(04).

Apellaniz, E., Baceta, J.I., Bernaola-Bilbao, G., Núñez-Betelu, K., Orue-Etxebarria, X., Payros, A., Pujalte, V., Robin, E. \& Rocchia, R. 1996. Analysis of uppermost Cretaceouslowermost Tertiary hemipelagic successions in the Basque Country (Western Pyrenees): evidence for a sudden extinction of more than half planktic foraminifer species at the K/T boundary. Bulletin de la Societé Géologique de France, 168, 783-793.

Arenillas, I. \& Molina, E. 1996. Bioestratigrafía y evolución de las asociaciones de foraminíferos planctónicos del tránsito Paleoceno-Eoceno en Alamedilla (Cordilleras Béticas). Revista Española de Micropaleontología, 28, 75-96,

Arreguín-Rodríguez, G.J., Alegret, L., Sepúlveda, J., Newman, S. \& Summons, R.E. 2014. Enhanced terrestrial input supporting the Glomospira acme across the PaleoceneEocene boundary in Southern Spain. Micropaleontology, 60, 43-51,

Astibia, H., Rodríguez-Tovar, F.J., Díaz-Martínez, I., Payros, A. \& Ortiz, S. 2017. Trace fossils from the Middle and Upper Eocene (Bartonian-Priabonian) molasse deposits of the Pamplona Basin (Navarre, western Pyrenees): palaeoenvironmental implications. Geological Journal, 52, 327-349; doi: 10.1002/gj.2763.

Aubry, M.P., Kaiho, K., Wright, J.D., Cramer, B. \& Lamolda, M.A. 2006. An expanded LPTM section at Caravaca: anatomy of a complex geological event. Climate and Biota of the Early Paleogene International Meeting, Volume of Abstract, p. 10.

Aubry, M.P., Ouda, K., Dupuis, C., Berggren, W.A., Van Couvering, J.A., Ali, J., Brinkhuis, H., Gingerich, P.R., Heilmann, C., Hooker, J., Kent, D.V., King, C., Knox, R., Laga, P., Molina, E., Schmitz, B., Steurbaut, E. \& Ward, D.R. 2007. The Global Standard Stratotype-section and Point (GSSP) for the base of the Eocene Series in the Dababiya section (Egypt). Episodes, 30, 271-286. 
Baceta, J.I., Pujalte, V., Serra-Kiel, J., Robador, A. \& OrueEtxebarria, X. 2004. El Maastrichtiense final, Paleoceno e Ilerdiense inferior de la Cordillera Pirenaica. In: Geología de España (ed. Vera, J.A.). Sociedad Geológica de España-Instituto Geológico y Minero de España, Madrid, 308-313.

Berggren, W.A. \& Aubert, J. 1975. Paleocene benthonic foraminiferal biostratigraphy, paleobiogeography and paleoecology of Atlantic-Tethyan regions: Midwaytype fauna. Palaeogeography, Palaeoclimatology, Palaeoecology, 18, 73-192; doi: 10.1016/00310182(75)90025-5.

Bernaola, G., Baceta, J.I., Orue-Extebarria, X., Alegret, L., Martín-Rubio, M., Arostegui, J. \& Dinarès-Turell, J. 2007. Evidence of an abrupt environmental disruption during the mid-Paleocene biotic event (Zumaia section, western Pyrenees). Geological Society of America Bulletin, 119, 785-795; doi: 10.1130/B26132.1.

Bornemann, A., Schulte, P., Sprong, J., Steurbaut, E., Youssef, M. \& Speijer, R.P. 2009. Latest Danian carbon isotope anomaly and associated environmental change in the southern Tethys (Nile Basin, Egypt). Journal of the Geological Society of London, 166, 1135-1142; doi: 10.1144/0016-76492008-104.

Bralower, T.J., Premoli Silva, I. \& Malone, M.J. 2002. New evidence for abrupt climate change in the Cretaceous and Paleogene: an Ocean Drilling Program expedition to Shatsky Rise, northwest Pacific. Geological Society of America. Today, 12, 4-10.

Brongniart, A.T. 1828. Histoire des Végétaux Fossiles ou Recherches Botaniques et Géologiques sur les Végétaux Renfermés dans les Diverses Couches du Globe, 1. G. Dufour and E. d'Ocagne, Paris.

Bybell, LM. \& Self-Trail, J.M. 1995. Evolutionary, biostratigraphic, and taxonomic study of calcareous nannofossils from a continuous Paleocene/Eocene boundary section in New Jersey. U.S. Geological Survey Professional Paper, 1554, 1-123.

Canudo, J.I. \& Molina, E. 1992. Planktic foraminiferal faunal turnover and biochronostratigraphy of the PaleoceneEocene boundary at Zumaya, northern Spain. Revista de la Sociedad Geológica de España, 5, 145-157.

Canudo, J.I., Keller, G., Molina, E. \& Ortiz, N. 1995. Planktic foraminiferal turnover and $\delta^{13} \mathrm{C}$ isotopes across the Paleocene-Eocene transition at Caravaca and Zumaya, Spain. Palaeogeography, Palaeoclimatology, Palaeoecology, 114, 75-100; doi: 10.1016/00310182(95)00073-U.

Coccioni, R., Bancalà, G., Catanzarit, R., Fornaciari, E., Frontalini, F., Giusberti, L., Jovane, L., Luciani, V., Savian, J. \& Sprovieri, M. 2012. An integrated stratigraphic record of the Palaeocene-lower Eocene at Gubbio (Italy): new insights into the early Palaeogene hyperthermals and carbon isotope excursions. Terra Nova, 24, 380-386; doi: 10.1111/j.1365-3121.2012.01076.x.

Comas, M.C. 1978. Sobre la geología de los Montes Orientales: Sedimentación y evolución paleogeográfica desde el Jurásico hasta el Mioceno inferior (zona
Subbética, Andalucía). PhD. Thesis, Universidad de Bilbao, 323 p.

De Paolo, D.J., Kyte, F.T., Marshall, B.D., O’Neill, J.R. \& Smit, J. 1983. Rb-Sr, Sm-Nd, K-Ca, O and H isotopic study of Cretaceous-Tertiary boundary sediments, Caravaca, Spain: evidence for an oceanic impact site. Earth Planet Science Letters, 64, 356-373; doi: 10.1016/0012-821X(83)90096-1.

Dickens, G.R., Castillo, M.M. \& Walker, J.G.C. 1997. A blast of gas in the latest Paleocene: Simulating first-order effects of massive dissociation of oceanic methane hydrate. Geology, 25, 259-262; doi: 10.1130/0091-7613(1997)025\%3C025 9:ABOGIT\%3E2.3.CO;2.

Dinarès-Turell, J., Pujalte, V., Stoykova, K., Baceta, J.I. \& Ivanov, M. 2012. The Palaeocene "top chron C27n" transient greenhouse episode: evidence from marine pelagic Atlantic and peri-Tethyan sections. Terra Nova, 24, 477-486; doi: 10.1111/j.1365-3121.2012.01086.x.

Domingo, L., López-Martínez, N., Leng, M.J. \& Grimes, S.T. 2009. The Paleocene-Eocene Thermal Maximum record in the organic matter of the Claret and Tendruy continental sections (South-Central Pyrenees, Lleida, Spain). Earth and Planetary Science Letters, 281, 226237; doi: 10.1016/j.eps1.2009.02.025.

D’Onofrio, R., Luciani, V., Fornaciari, E., Giusberti, L., Boscolo Galazzo, F., Dallanave, E., Westerhold, T., Sprovieri, M. \& Telch, S. 2016. Environmental perturbations at the early Eocene ETM2, H2 and I1 events as inferred by Tethyan calcareous plankton (Terche section, northeastern Italy). Paleoceanography, 31, doi:10.1002/2016PA002940.

Gingerich, P.D. 2003. Mammalian response to climate change at the Paleocene-Eocene boundary: Polecat Bench record in the northern Bighorn Basin, Wyoming. In: Causes and Consequences of Globally Warm Climates in the Early Paleogene (eds Wing, S.L., Gingerich, P.D., Schmitz, B. \& Thomas, E.). The Geological Society of America, Special Paper, 369, 463-478.

Giusberti, L., Boscolo Galazzo, F. \& Thomas, E. 2016. Variability in climate and productivity during the Paleocene-Eocene Thermal Maximum in the western Tethys (Forada section). Climate of the Past, 12, 213-240; doi: 10.5194/cp-12-213-2016.

Gonzalvo, C. \& Molina, E. 1998, Planktic foraminiferal biostratigraphy across the Lower-Middle Eocene transition in Betic Cordillera (Spain). Neues Jahrbuch für Geologie und Paläontologie, Monatshefte, 11, 671-603.

Guernet, C. \& Molina, E. 1997. Les ostracodes et le passage Paléocene-Éocène dans les Cordillères Bétiques (Coupe de Caravaca, Espagne). Geobios, 30, 32-43; doi: 10.1016/ S0016-6995(97)80255-0.

Hillebrandt, A.V. 1974. Bioestratigrafía del Paleógeno en el Sureste de España (Prov. de Murcia y Alicante). Cuadernos de Geología, 5, 135-153.

Hönisch, B., Ridgwell, A., Schmidt, D.N., Thomas, E., Gibbs, S.J., Sluijs, A., Zeebe, R., Kump, L., Martindale, R.C., Greene, S.E., Kiessling, W., Ries, J., Zachos, J.C., Royer, D.L., Barker, S., Marchitto, T.M., Moyer, R., Pelejero, 
C., Ziveri, P., Foster, G.L. \& Williams, B. 2012. The geological record of ocean acidification. Science, 335, 1058-1963; doi: 10.1126/science.1208277.

Hyland, E.G., Sheldon, N.D. \& Cotton, J.M. 2015. Terrestrial evidence for a two-stage mid-Paleocene biotic event. Palaeogeography, Palaeoclimatology, Palaeoecology, 417, 371-378; doi: 10.1016/j.palaeo.2014.09.031.

Kaiho, K. \& Lamolda, M.A. 1999. Catastrophic extinction of planktonic foraminifera at the Cretaceous-Tertiary boundary evidenced by stable isotopes and foraminiferal abundance at Caravaca, Spain. Geology, 27, 355-358; doi: 10.1130/0091-7613(1999)027\%3C0355:CEOPFA\% 3E2.3.CO;2.

Kedzierski, M., Rodríguez-Tovar, F.J. \& Uchman, A. 2011. Vertical displacement and taphonomic filtering of nannofossils by bioturbation in the Cretaceous-Palaeogene boundary section at Caravaca, SE Spain. Lethaia, 44, 321-328; doi:10.1111/j.1502-3931.2010.00244.

Kelly, D.C., Bralower, T.J. \& Zachos, J.C. 1998. Evolutionary consequences of the latest Paleocene thermal maximum for tropical planktonic foraminifera. Palaeogeography, 141, 139-161; doi: 10.1016/S0031-0182(98)00017-0.

Klappa, C.F. 1978. Biolithogenesis of Microcodium: elucidation. Sedimentology, 25, 489-522; doi: 10.1111/ j.1365-3091.1978.tb02077.x.

Koch, P.L., Zachos, J.C. \& Gingerich, P.D. 1992. Correlation between isotope records in marine and continental carbon reservoirs near the Paleocene/Eocene boundary. Nature, 322, 358-319; doi: 10.1038/358319a0.

Kosir, A. 2004. Microcodium revisited: root calcification products of terrestrial plants on carbonate-rich substrates. Journal of Sedimentary Research, 74, 845-857; doi: 10.1306/040404740845.

Ksiąźkiewicz, M. 1977. Trace fossils in the flysch of the Polish Carpathians. Palaeontologia Polonica, 36, 1-208.

Lourens, L.J., Sluijs, A., Kroon, D., Zachos, J.C., Thomas, E., Röhl, U., Bowles, J. \& Raffi, I. 2005. Astronomical pacing of late Paleocene to early Eocene global warming events. Nature, 435, 1083-1087; doi: 10.1038/nature03814.

Lu, G., Adatte, T., Keller, G. \& Ortiz, N. 1998. Abrupt climatic, oceanographic and ecological changes near the Paleocene-Eocene transition in the deep Tethys basin: The Alamedilla section, southern Spain. Eclogae Geologicae Helvetiae, 91, 293-306.

Luo Y., Boudreau, B.P., Dickens, G.R., Sluijs, A. \& Middelburg, J.J. 2016. An alternative model for $\mathrm{CaCO}_{3}$ over-shooting during the PETM: Biological carbonate compensation. Earth and Planetary Science Letters, 453, 223-233; doi: 10.1016/j.epsl.2016.08.012.

Martínez Gallego, J. 1977. Estudio micropaleontológico del Nummulítico de un sector comprendido entre MoredaPiñar-Pedro Martínez (Zona Subbética). Tesis Doctorales de la Universidad de Granada 175, tomo 1, 241 p.

Martini, E. 1971. Standard Tertiary and Quaternary calcareous nannoplankton zonation. In: Proceeding of the 2nd International Conference of Planktonic Microfossils, Roma (ed. Farinacci, A.). Editioni Tecnosciencia, Rome, 2, 739-785.
Mary, C., Moreau, M.G., Orue-Etxebarria, X., Apellaniz, E. \& Courtillot, V. 1991. Biostratigraphy and magnetostratigraphy of the Cretaceous/Tertiary Sopelana Section (Basque Country). Earth and Planetary Science Letters, 106, 133150; doi: 10.1016/0012-821X(91)90068-S.

McInerney, F.A. \& Wing, S.L. 2011. The Paleocene-Eocene thermal maximum: A perturbation of carbon cycle, climate, and biosphere with implications for the future. Annual Review of Earth and Planetary Sciences, 39, 489-516; doi: 10.1146/annurev-earth-040610-133431.

Minelli, N., Manzi, V. \& Roveri, M. 2013. The record of the Paleocene-Eocene thermal maximum in the Ager Basin (Central Pyrenees, Spain). Geologica Acta, 11, 421-441; doi: 10.1344/105.000002061.

Molina, E. 2015. Evidence and causes of the main extinction events in the Paleogene based on extinction and survival patterns of foraminifera. Earth-Science Reviews, 140, 166-181; doi: 10.1016/j.earscirev.2014.11.008.

Molina, E., Canudo, J., Martínez Ruiz, F. \& Ortiz, N. 1994. Integrated stratigraphy across the Paleocene/ Eocene boundary at Caravaca, southern Spain. Eclogae Geologicae Helvetiae, 87, 47-61.

Molina, J.M., Vera, J.A. \& Aguado, R. 2006. Reworked Microcodium calcarenites interbedded in pelagic sedimentary rocks (Paleocene, Subbetic, southern Spain): Paleoenvironmental reconstruction. In: Paleoenvironmental Record and Applications of Calcretes and Palustrine Carbonates (eds Alonso-Zarza, M.A. \& Tanner, L.H.). Geological Society of America Special Paper, 416, 189-202; doi: 10.1130/2006.2416(12).

Monechi, S., Angori, E. \& Von Salis, K. 2000. Calcareous nannofossil turnover around the Paleocene/Eocene transition at Alamedilla (southern Spain). Bulletin de la Société géologique de France, 171, 477-489; doi: 10.2113/171.4.477.

Monechi, S., Reale, V., Bernaola, G. \& Balestra, B. 2012. The Danian/Selandian boundary at Site 1262 (South Atlantic) and in the Tethyan region: Biomagnetostratigraphy, evolutionary trends in fasciculiths and environmental effects of the Latest Danian Event. Marine Micropaleontology, 98, 28-40; doi: 10.1016/j.marmicro.2012.11.002.

Nicolo, M.J., Dickens, G.R., Hollis, C.J. \& Zachos, J.C. 2007. Multiple early Eocene hyperthermals: their sedimentary expression on the New Zealand continental margin and in the deep sea. Geology, 35, 699-702; doi: 10.1130/ G23648A.1.

Okada, H. \& Bukry, D. 1980. Supplementary modification and introduction of code numbers to the low-latitude coccolith biostratigraphic zonation (Bukry, 1973; 1975). Marine Micropaleontology, 5, 321-325; doi: 10.1016/03778398(80)90016-X.

Orue-Etxebarria, X., Bernaola, G., Baceta, J.I., Angori, E., Caballero, F., Monechi, S., Pujalte, V., Dinarès-Turell, J., Apellaniz, E. \& Payros, A. 2004. New constraints on the evolution of planktic foraminifers and calcareous nannofossils across the Paleocene/ Eocene boundary interval: the Zumaia section revisited. Neues Jahrbuch für Geologie und Paläontologie, Abh., 234, 223-259. 
Orue-Etxebarria, X., Payros, A., Bernaola, G., Dinarès-Turell, J., Tosquella, J., Apellaniz, E. \& Caballero, F. 2006. The Ypresian/Lutetian boundary at the Gorrondatxe beach section (Basque Country, W Pyrennees). Climate and Biota of the Early Paleogene. Mid Conference Field Excursion Guidebook, Bilbao. 36 pp.

Payros, A., Ortiz, S., Alegret, L., Orue-Etxebarria, X., Apellaniz, E. \& Molina, E. 2012. An early Lutetian carboncycle perturbation: Insights from the Gorrondatxe section (western Pyrenees, Bay of Biscay). Paleoceanography, 27, PA2213; doi: 10.1029/2012PA002300.

Penman, D.E., Turner, S.K., Sexton, P.F., Norris, R.D., Dickson, A.J., Boulila, S., Ridgwell, A., Zeebe, R.E., Zachos, J.C., Cameron, A., Westerhold, T. \& Röhl, U. 2016. An abyssal carbonate compensation depth overshoot in the aftermath of the Palaeocene-Eocene Thermal Maximum. Nature Geoscience, 9, 575-580; doi: 10.1038/ ngeo 2757.

Petrizzo, M.R. 2005, An early late Paleocene event on Shatsky Rise, northwest Pacific Ocean (ODP Leg 198): Evidence from planktonic foraminiferal assemblages. Proceedings of the Ocean Drilling Program, Scientific Results, 198, http://www-odp.tamu. edu/publications/198_SR/102/102. htm.

Pujalte, V., Orue-Etxebarria, X., Schmitz, B., Tosquella, J., Baceta, J.I., Payros, A., Bernaola, G., Caballero, F. \& Apellaniz, E. 2003. Basal Ilerdian (earliest Eocene) turnover of larger foraminifera: age constraints based on calcareous plankton and $\delta^{13} \mathrm{C}$ isotopic profiles from new southern Pyrenean sections (Spain). In: Causes and Consequences of Globally Warm Climates in the Early Paleogene (eds Wing, S.L., Gingerich, P.D., Schmitz, B. \& Thomas, E.). Geological Society of America, Special Paper 369, pp. 205-221.

Pujalte, V., Baceta, J.I., Schmitz, B., Orue-Etxebarria, X., Payros, A., Bernaola, G., Apellaniz, E., Caballero, F., Robador, A., Serra-Kiel, J. \& Tosquella, J. 2009. Redefinition of the Ilerdian Stage (early Eocene). Geologica Acta, 7, 177-194; doi: 10.1344/105.000000268.

Pujalte, V., Orue-Etxebarria, X., Apellaniz, E., Caballero, F. \& Robles, S. 2012. Río Gor, comarca de Guadix, provincia de Granada: una nueva sección de referencia del Paleógeno inferior Subbético. Geogaceta, 52, 53-56.

Pujalte, V., Orue-Etxebarria, X., Apellaniz, E. \& Caballero, F. 2014a. El Paleógeno inferior de los Montes Orientales, provincia de Granada, Zona Subbética: revisión y nuevos datos. Revista de la Sociedad Geológica de España, 27, 137-149.

Pujalte, V., Orue-Etxebarria, X., Apellaniz, E., Caballero, F., Monechi, S., Ortiz, S. \& Schmitz, B. 2014b. A prospective Early Late Paleocene event (ELPE) from the expanded Río Gor hemipelagic section (Betic Cordillera, southern Spain): foraminifera, nannofossil and isotopic data. Rendiconti Online della Società Geologica Italiana, 31, 181-182; doi: 10.3301/ROL.2014.110.

Pujalte, V., Baceta, J.I. \& Schmitz, B. 2015a. A massive input of coarse-grained siliciclastics in the Pyrenean Basin during the PETM: the missing ingredient in a coeval abrupt change in hydrological regime. Climate of the Past, 11, 1653-1672; doi: 10.5194/cp-11-1653-2015. Discussion paper, doi: 10.5194/cp-11-1653-2015.

Pujalte, V., Molina, J.M., Apellaniz, E., Caballero, F., Ortiz, S., Orue-Etxebarria, X. \& Rodriguez, J. 2015 b. Tempestites? Turbidites? Contourites? The Lower Paleocene Microcodium-bearing calcarenites of the Spanish Subbetic Zone revisited. 31th Meeting of the International Association of Sedimentologists (IAS), Abstract Book, p. 432.

Pujalte, V., Robador, A., Payros, A. \& Samsó, J.M. 2016. A siliciclastic braid delta within a lower Paleogene carbonate platform (Ordesa-Monte Perdido National Park, southern Pyrenees, Spain): Record of the Paleocene-Eocene Thermal Maximum perturbation. Palaeogeography, Palaeoclimatology, Palaeoecology, 459, 453-470; doi: 10.1016/j.palaeo.2016.07.029.

Robador, A., Pujalte, V., Samsó, J.M. \& Payros, A. 2009. Registro geológico del máximo térmico del PaleocenoEoceno en el Parque Nacional de Ordesa y Monte Perdido (Pirineo Central). Geogaceta, 46, 111-114.

Rodríguez-Tovar, F.J. \& Uchman, A. 2006. Ichnological analysis of the Cretaceous- Palaeogene boundary interval at the Caravaca section, SE Spain. Palaeogeography, Palaeoclimatology, Palaeoecology, 242, 313-325; doi: 10.1016/j.palaeo.2006.06.006.

Rodríguez-Tovar, F.J. \& Uchman, A. 2008. Bioturbational disturbance of the Cretaceous-Paleogene $(\mathrm{K} / \mathrm{Pg})$ boundary layer: implications for the interpretation of the $\mathrm{KePg}$ boundary impact event. Geobios, 41, 661-667; doi: 10.1016/j.geobios.2008.01.003.

Rodríguez-Tovar, F.J., Uchman, A., Payros, A., OrueEtxebarria, X., Apellaniz, E. \& Molina, E. 2010. Sealevel dynamics and palaeoecological factors affecting trace fossil distribution in Eocene turbiditic deposits (Gorrondatxe section, N Spain). Palaeogeography, Palaeoclimatology, Palaeoecology, 285, 50-65; doi: 10.1016/j.palaeo.2009.10.022.

Rodríguez-Tovar, F.J., Uchman, A., Alegret, L. \& Molina, E. 2011. Impact of the Paleocene-Eocene Thermal Maximum on the macrobenthic community: ichnological record from the Zumaia section, northern Spain. Marine Geology, 282, 178-187; doi: 10.1016/j.margeo.2011.02.009.

Rodríguez-Tovar, F.J., Piñuela, L. \& García-Ramos, J.C. 2016. Trace fossils assemblages from the Cenozoic "flysch units" of the Campo de Gibraltar Complex (southern Spain). Ichnos, 23, 53-70; doi: 10.1080/10420940.2015.1130708.

Röhl, U., Westerhold, T., Monechi, S., Thomas, E., Zachos, J.C. \& Donner, B. 2005. The third and final Early Eocene Thermal Maximum: characteristics, timing and mechanisms of the X Event. 37th Annual Meeting, Salt Lake City, USA, Abstract, Geological Society of America, 264.

Roldán-García, F.J., Lupiani Moreno, E, Villalobos Megía, M., Hidalgo Ruiz, J. \& Soria Mingorance, J. 2009. Mapa Geológico de España 1:50.000, hoja 971 (Cuevas del Campo) y Memoria. IGME. 65 p.

Schmitz, B. \& Pujalte, V. 2003. Sea-level, humidity, and land-erosion records across the initial Eocene Thermal 
Maximum from a continental-marine transect in northern Spain. Geology, 31, 689-692; doi: 10.1130/G19527.1.

Schmitz, B., Asaro, F., Molina, E., Monechi, S., Von Salis, K. \& Speijer, R. 1997. High-resolution iridium, $\delta^{13} \mathrm{C}$, $\delta^{18} \mathrm{O}$, foraminifera and nannofossil profiles across the latest Paleocene benthic extinction event at Zumaya. Palaeogeography, Palaeoclimatology, Palaeoecology, 133, 49-68; doi: 10.1016/S0031-0182(97)00024-2.

Schmitz, B., Pujalte, V. \& Núnez-Betelu, K. 2001. Climate and sea-level perturbations during the Initial Eocene Thermal Maximum: Evidence from siliciclastic units in the Basque Basin (Ermua, Zumaya and Trabakua Pass), northern Spain. Palaeogeography, Palaeoclimatology, Palaeoecology, 165, 299-320; doi: 10.1016/S00310182(00)00167-X.

Schmitz, B. \& Pujalte, V. 2007. Abrupt increase in seasonal extreme precipitation at the Paleocene-Eocene boundary. Geology, 35, 215-218; doi: 10.1130/G23261A.1.

Schmitz, B., Pujalte, V., Molina, E., Monechi, S., OrueEtxebarria, X., Speijer, R.P., Alegret, L., Apellaniz, E., Arenillas, I., Aubry, M.P., Baceta, J.I., Berggren, W.A., Bernaola, G., Caballero, F., Clemmensen, A., DinarèsTurell, J., Dupuis, C., Heilman-Clausen, C., Hilario Orus, A., Knox, R. Martín-Rubio, M., Ortiz, S. Payros, A., Petrizzo, M.R., von Salis, K., Sprong, J., Steurbaut, E. \& Thomsen, E. 2011. The Global Stratotype Section and Points for the bases of the Selandian (Middle Paleocene) and Thanetian (Upper Paleocene) stages at Zumaia, Spain. Episodes, 34, 220-243.

Schulte, P., Bornemann, A. \& Speijer, R.P. 2010. The Top Chron C27n Event on the Western Atlantic: evidence for a transient perturbation of the carbon cycle in the Late Danian. Geophysical Research Abstracts, 12, EGU201013049, EGU General Assembly 2010.

Sluijs, A., Bowen, G.J., Brinkhuis, H., Lourens, L.J. \& Thomas, E. 2007. The Paleocene-Eocene Thermal maximum super greenhouse: biotic and geochemical signatures, age models and mechanisms of climate change. In: Deep Time Perspectives on Climate Change: Marrying the Signal from Computer Models and Biological Proxies (eds Williams, M., Haywood, A.M., Gregory, F.J. \& Schmidt, D.N.). The Micropalaeontological Society, Special Publication, The Geological Society, London, pp. 323-351.

Smit, J. 1979. The Cretaceous/Tertiary transition in the Barranco del Gredero, Spain. In: Cretaceous-Tertiary Boundary Events Symposium. II. Proceedings, (eds Christensen, W.K. \& Birkelund. T.). Copenhagen, 156-163.

Smit, J. 2004. The section of the Barranco del Gredero (Caravaca, SE Spain): a crucial section for the Cretaceous/ Tertiary boundary impact extinction hypothesis. Journal of Iberian Geology, 31, 179-191.

Sosa-Montes de Oca, C., Martínez-Ruiz, F. \& RodríguezTovar, F.J. 2013. Bottom water conditions in a marine basin after the Cretaceous-Paleogene impact event: timing the recovery of oxygen levels and productivity. Plos One, 8(12), e82242; doi: 10.1371/journal.pone.0082242.

Sosa-Montes de Oca, C., Rodríguez-Tovar, F.J. \& MartínezRuiz, F. 2016. Geochemical and isotopic characterization of trace fossil infillings: New insights on tracemaker activity after the K/Pg impact event. Cretaceous Research, 57, 391-401; doi: 10.1016/j.cretres.2015.03.003.

Stap, L., Lourens, L.J., Thomas, E., Sluijs, A., Bohaty, S.M. \& Zachos, J.C. 2010. High-resolution deep-sea carbon and oxygen isotope records of Eocene Thermal Maximum 2 and H2. Geology, 38, 607-610; doi: 10.1130/G30777.1.

Storme, J.-Y., Devleeschouwer, X., Schnyder, J., Cambier, G., Baceta, J.I., Pujalte, V., Di Matteo, A., Iacumin, P. \& Yans, J. 2012. The Palaeocene/Eocene boundary section at Zumaia (Basque-Cantabric Basin) revisited: new insights from high-resolution magnetic susceptibility and carbon isotope chemostratigraphy on organic matter $\left(\delta^{13} \mathrm{Corg}\right)$. Terra Nova, 24, 310-317; doi: 10.1111/j.13653121.2012.01064.x.

Thomas, E. 1998. Biogeography of the late Paleocene benthic foraminiferal extinction. In: Late Paleocene-Early Eocene Climatic and Biotic Events in the Marine and Terrestrial Records (Aubry, M.P., Lucas, S. \& Berggren, W. A. eds). Columbia University Press, New York, 214-243.

Thomas, E. 2007. Cenozoic mass extinctions in the deep sea: what perturbs the largest habitat on Earth? In: Large Ecosystem Perturbations: Causes and Consequences, (eds Monechi, S., Coccioni, R. \& Rampino, M.). Geological Society of America Society, Boulder, Colorado, 424, $1-23$.

Thomas, E. \& Shackleton, N.J. 1996. The PaleoceneEocene benthic foraminiferal extinction and stable isotopes anomalies. Geological Society of London, Special Publications, 101, 401-441; doi: 10.1144/GSL. SP.1996.101.01.20.

Thomas, E. \& Zachos, J.C. 2000. Was the late Paleocene thermal maximum a unique event? GFF, 122, 169-170; doi: 10.1080/11035890001221169.

Tjalsma, R.C. \& Lohmann, G.P. 1983. Paleocene-Eocene bathyal and abyssal benthic foraminifera from the Atlantic Ocean. Micropaleontology, 4, 1-90.

Uchman, A. 1995. Taxonomy and palaeoecology of flysch trace fossils: The Marnosoarenacea Formation and associated facies (Miocene, Northern Apennines, Italy). Beringeria, 15, 1-115.

Uchman, A. 1998. Taxonomy and ethology of flysch trace fossils: revision of the Marian Książkiewicz collection and studies of complementary material. Annales. Societatis Geologorum Poloniae, 68, 105-218.

Uchman, A. 1999. Ichnology of the Rhenodanubian Flysch (Lower Cretaceous-Eocene) in Austria and Germany. Beringeria, 25, 67-173.

Uchman, A. 2001. Eocene flysch trace fossils from the Hecho Group of the Pyrenees, northern Spain. Beringeria, 28, $3-41$.

Uchman, A. 2009. The Ophiomorpha rudis ichnosubfacies of the Nereites ichnofacies: characteristics and constraints. Palaeogeography, Palaeoclimatology, Palaeoecology, 276, 107-119; doi: 10.1016/j.palaeo.2009.03.003.

Uchman, A. \& Wetzel, A. 2011. Deep-sea ichnology: the relationships between depositional environment and endobenthic organisms. In: Deep-Sea Sediments, 
(eds Hüneke, H. \& Mulder, T.). Developments in Sedimentology, 63, 517-556.

Van Morkhoven, F.P.C.M., Berggren, W.A. \& Edwards, A.S. 1986. Cenozoic cosmopolitan deep-water benthic foraminifera. Bulletin des Centres de Recherches Exploration-Production Elf-Aquitaine, 11, 1-421.

Van Veen, G.W. 1969. Geological investigations in the region west of Caravaca, south-eastern Spain. PhD Thesis Amsterdam, University.

Vera, J.A. 2004. Cordillera Bética y Baleares. In: Geología de España (ed. Vera, J.A.). SGE-IGME, Madrid, 347-527.

Vera, J.A., García-Hernández, M., López-Garrido, A.C., Comas, M.C., Ruiz-Ortíz, P.A. \& Martín-Algarra, A. 1982. El Cretácico de la Cordillera Bética. In: El Cretácico de España (ed. García, A.). Editorial Complutense, Madrid, 515-632.

Vera, J.A. \& Molina, J.M. (1999). La Formación Capas Rojas: caracterización y génesis. Estudios Geológicos, 55, 45-66.

Wade, B.S., Pearson, P.N., Berggren, W.A. \& Pälike, H. 2011. Review and revision of Cenozoic tropical planktonic foraminiferal biostratigraphy and calibration to the geomagnetic polarity and astronomical time scale. Earth-Science Reviews, 104, 111-142; doi: 10.1016/j. earscirev.2010.09.003.
Wing, S.L., Harrington, G.J., Smith, F.A., Bloch, J.I., Boyer, D.M. \& Freeman, K.H. 2005. Transient floral change and rapid global warming at the Paleocene-Eocene boundary. Science, 310, 993-996; doi: 10.1126/science.1116913.

Zachos, J.C., Röhl, U., Schellenberg, S.A., Sluijs, A., Hodell, D.A., Kelly, D.C., Thomas, E., Nicolo, M., Raffi, I., Lourens, L.J., McCarren, H. \& Kroon, D. 2005. Rapid acidification of the ocean during the Paleocene Eocene thermal maximum. Science, 308, 1611-1615; doi: 10.1126/science.1109004.

Zachos, J.C., Dickens, G.R. \& Zeebe, R.E. 2008. An early Cenozoic perspective on greenhouse warming and carboncycle dynamics. Nature, 451, 279-283; doi: 10.1038/ nature 06588 .

Zachos, J.C., McCarren, H., Murphy, B., Röhl, U. \& Westerhold, T. 2010. Tempo and scale of late Paleocene and early Eocene carbon isotope cycles: implications for the origin of hyperthermals. Earth and Planetary Science Letters, 299, 242-249; doi: 10.1016/j.epsl.2010.09.004.

Zeebe, R.E., Zachos, J.C. \& Dickens, G.R. 2009. Carbon dioxide forcing alone insufficient to explain PaleoceneEocene Thermal Maximum warming. Nature Geoscience, 2, 576-580; doi: 10.1038/ngeo578. 